\title{
Mercury (Hg) Contaminated Sites in Kazakhstan: Review of Current Cases and Site Remediation Responses
}

\author{
Mert Guney ${ }^{1,2, *(\mathbb{C}) \text {, Zhanel Akimzhanova }}{ }^{1,2}$, Aiganym Kumisbek ${ }^{1,2}$, Kamila Beisova ${ }^{1,2}$, \\ Symbat Kismelyeva ${ }^{1,2}$, Aliya Satayeva ${ }^{1,3}$, Vassilis Inglezakis ${ }^{4(-)}$ and Ferhat Karaca ${ }^{1,2}(\mathbb{C})$ \\ 1 The Environment \& Resource Efficiency Cluster (EREC), Nazarbayev University, \\ Nur-Sultan 010000, Kazakhstan; zhanel.akimzhanova@nu.edu.kz (Z.A.); \\ aiganym.kumisbek@nu.edu.kz (A.K.); kamila.beisova@nu.edu.kz (K.B.); \\ symbat.kismelyeva@nu.edu.kz (S.K.); aliya.satayeva@nu.edu.kz (A.S.); ferhat.karaca@nu.edu.kz (F.K.) \\ 2 Environmental Science \& Technology Group (ESTg), Department of Civil and Environmental Engineering, \\ Nazarbayev University, Nur-Sultan 010000, Kazakhstan \\ 3 Environmental Science \& Technology Group (ESTg), Department of Chemical and Materials Engineering, \\ Nazarbayev University, Nur-Sultan 010000, Kazakhstan \\ 4 Chemical and Process Engineering, University of Strathclyde, Glasgow G1 1XQ, UK; \\ vasileios.inglezakis@strath.ac.uk \\ * Correspondence: mert.guney@nu.edu.kz
}

Received: 9 October 2020; Accepted: 27 November 2020; Published: 1 December 2020

check for updates

\begin{abstract}
Mercury (Hg) emissions from anthropogenic sources pose a global problem. In Central Asia, Kazakhstan's central and northern regions are among the most severely Hg-contaminated territories. This is due to two former acetaldehyde (in Temirtau) and chlor-alkali (in Pavlodar) plants, discharges from which during the second half of the 20th century were estimated over 2000 tons of elemental Hg. However, the exact quantities of $\mathrm{Hg}$ released through atmospheric emissions to the environment, controlled discharges to the nearby aquatic systems, leakages in the cell plant, and contaminated sludge are still unknown. The present review is the initiation of a comprehensive field investigation study on the current state of these contaminated sites. It aims to provide a critical review of published literature on $\mathrm{Hg}$ in soils, sediments, water, and biota of the impacted ecosystems (Nura and Irtysh rivers, and Lake Balkyldak and their surrounding areas). It furthermore compares these contamination episodes with selected similar international cases as well as reviews and recommends demercuration efforts. The findings indicate that the contamination around the acetaldehyde plant site was significant and mainly localized with the majority of $\mathrm{Hg}$ deposited in topsoils and riverbanks within $25 \mathrm{~km}$ from the discharge point. In the chlor-alkali plant site, Lake Balkyldak in North Kazakhstan is the most seriously contaminated receptor. The local population of both regions might still be exposed to $\mathrm{Hg}$ due to fish consumption illegally caught from local rivers and reservoirs. Since the present field data is limited mainly to investigations conducted before 2010 and given the persisting contamination and nature of $\mathrm{Hg}$, a recent up-to-date environmental assessment for both sites is highly needed, particularly around formerly detected hotspots. Due to incomplete site remediation efforts, recommendations given by several researchers for the territories of the former chlor-alkali and acetaldehyde plant site include ex-situ soil washing, soil pulping with gravitational separation, ultrasound and transgenic algae for sediments, and electrokinetic recovery for the former and removal and/or confinement of contaminated silt deposits and soils for the latter. However, their efficiency first needs to be validated. Findings and lessons from these sites will be useful not only on the local scale but also are valuable resources for the assessment and management of similar contaminated sites around the globe.
\end{abstract}


Keywords: acetaldehyde plant; chlor-alkali plant; contaminated sites; Lake Balkyldak; mercury removal; Nura River; site contamination; soil and sediment pollution; soil treatment

\section{Introduction}

Mercury ( $\mathrm{Hg}$ ) and its common compounds (e.g., $\mathrm{HgS}$ (cinnabar), $\mathrm{HgCl}_{2}$ ) are persistent, highly bioaccumulating, very toxic to people and the environment [1]. They are released to ecosystems by both natural and anthropogenic processes [2,3]. $\mathrm{Hg}$ exists in the environment mainly in the form of elemental $\left(\mathrm{Hg}^{0}\right)$, inorganic (i.e., ionic: $\mathrm{Hg}^{+}$and $\left.\mathrm{Hg}^{2+}\right)$, and organic species $\left(\mathrm{MeHg}^{+}, \mathrm{MeHg}^{2+}, \mathrm{EtHg}^{+}\right.$, etc.) [2,4]. Anthropogenic processes with the highest contribution to global $\mathrm{Hg}$ release include disposal of batteries [5] and energy-efficient lamps [6], mining and mine wastes [7], fossil fuel combustion (mainly coal) [8], leather tannery [9] and other industrial activities, including the manufacturing of chlor-alkali and caustic soda using Hg-cell. Moreover, due to the $\mathrm{Hg}$ cycle through the air, water, and soil, re-emissions of $\mathrm{Hg}$ from $\mathrm{Hg}$-contaminated areas, including natural and anthropogenic sources of the past, are also significant drivers of the total $\mathrm{Hg}$ releases, especially to the atmosphere [10].

In addition to being persistent, $\mathrm{Hg}$ released to the atmosphere can travel long distances making localized discharges a global concern [1,11]. However, in general, atmospheric Hg concentrations are rarely above risk-inducing levels, and the major problem with long-range transport of $\mathrm{Hg}$ is its deposition and subsequent introduction to the food chain [1]. Hg in ambient air exists mainly in the form of elemental $\mathrm{Hg}[10,12,13]$, but there are more $\mathrm{Hg}$ compounds in water with varying solubilities: $\mathrm{Hg}(\mathrm{II})$ chloride is readily soluble, $\mathrm{Hg}(\mathrm{I})$ chloride and $\mathrm{HgS}$ are less soluble, and $\mathrm{Hg}^{0}$ is insoluble in water [14]. Inorganic Hg is then methylated in water by bacterial species (Pseudomonas) in biota, which leads to the formation of very toxic methylmercury (MeHg) that can enter the food chain of the aquatic ecosystem [14]. Waterbed sediments act as a buffer medium and, depending on the environmental conditions, can accumulate or liberate $\mathrm{Hg}$ [15]. $\mathrm{Hg}$ may be naturally present in soils in the form of $\mathrm{Hg}$ salts and minerals [16], and also come from the wet or dry deposition of airborne $\mathrm{Hg}$ or industrial discharges [13]. Atypical to compartments other than air, elemental $\mathrm{Hg}$ might be found massively in contaminated soils, for example, in the case of spillage [8]. However, more common forms of $\mathrm{Hg}$ present in soil include inorganic $\mathrm{Hg}$ (e.g., in $\mathrm{HgCl}_{2}, \mathrm{HgO}, \mathrm{HgS}$ ) and, given specific circumstances, organic $\mathrm{Hg}$ (not be mistaken with inorganic $\mathrm{Hg}$ salts and minerals attached to organic matter) [13]. Different forms of $\mathrm{Hg}$ in various compartments exhibit different physicochemical behaviors [16], which makes investigating the fate and transport of $\mathrm{Hg}$ extremely difficult [17].

There have been two major Hg contamination episodes in Kazakhstan: (1) a chlor-alkali plant operated in Pavlodar based on Hg-cell technology and (2) a carbide-aldehyde plant located on the banks of Nura River in Temirtau (Figure 1). The former PO "Khimprom" chlor-alkali plant (at present active as JSC "Pavlodar Chemical Plant" (PCP)) in Pavlodar operated in 1975-1993. It manufactured chemicals for both civilian and military uses; primarily, chlorine and caustic soda using Hg-cell method [18]. Several settling lagoons, including Lake Balkyldak (located north of the plant), were formed and explicitly used for industrial waste such as Hg-rich sludge [19]. The second, the Industrial Complex JSC "Carbide" (at present "Karaganda Plant SK Temirtau") produced carbide and acetaldehyde. It has been the primary source of $\mathrm{Hg}$ contamination in Central Kazakhstan from 1950 to 1997 [20]. Although from the mid-1970s to the mid-1990s, the wastewater discharged from JSC Carbide has been treated, the discharges to the Nura River and Samarkand reservoir still had high $\mathrm{Hg}$ content. The sediments and river water in the vicinity of the main discharge drain still contain high $\mathrm{Hg}$ concentrations [21]. Discharges and losses from both of these facilities contained over $2000 \mathrm{t}$ of $\mathrm{Hg}$ combined and created the major Hg contamination cases in Kazakhstan's history, which are still not thoroughly assessed to this date. 


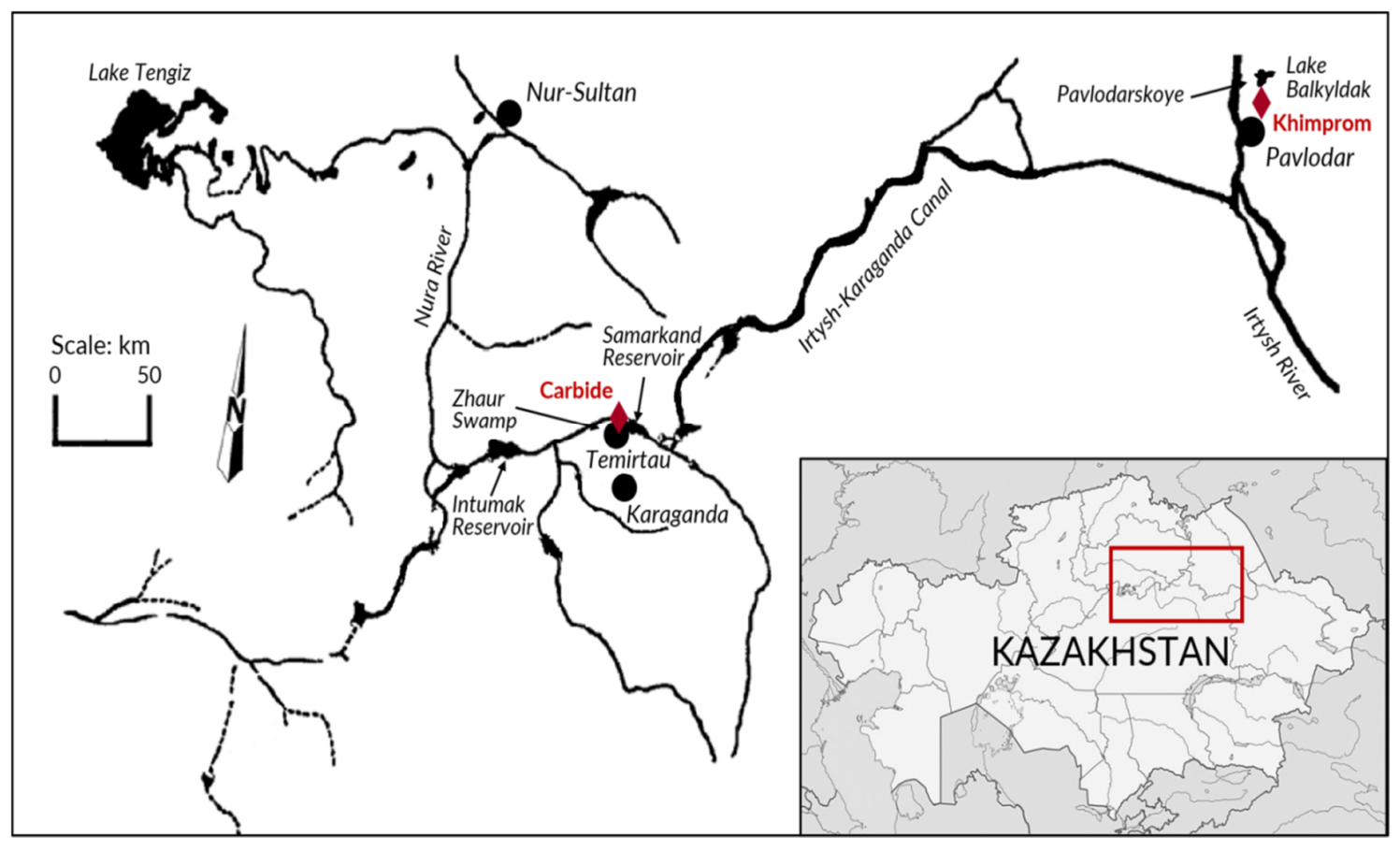

Figure 1. Map showing Hg-contaminated sites in Kazakhstan (adapted from [22]).

The present paper is the initial output of a comprehensive site re-assessment project that aims to provide an overview of the current state of $\mathrm{Hg}$ contamination in Kazakhstan. Its objectives are (1) to review Hg-contaminated sites in Kazakhstan as situated in its northern and central regions, (2) to provide their detailed analysis and comparison with the literature, and (3) to review and summarize remediation recommendations for Hg-contaminated sites. We further aim the present review to serve as a resource at international level regarding the assessment, rehabilitation, and management of Hg-contaminated sites by similar industrial activities. Multiple comparable cases are present around the globe, particularly in Eastern Europe and East Asia where identical/related industrial processes using $\mathrm{Hg}$ have been employed.

Given the specifics of the contamination cases, the study's scope was limited to media acting as a "sink," i.e., soil, sediment, water, and biota. The scarce and fragmented literature on the subject has been critically reviewed. The current situation regarding the exposure assessment has been presented, and mitigation, remediation, and research recommendations have been addressed. A comprehensive literature review on $\mathrm{Hg}$ contamination in Pavlodar and Nura River regions has been performed using the platforms including international journal databases and local publications. Studies investigating the concentrations of several contaminants along with $\mathrm{Hg}$ levels have also been included. The majority of the studies reviewed in the present work have been published before 2010 as both contamination incidents occurred more than 20 years ago. Mainly, relevant high quality works published in the first (Q1) and second (Q2) quartile journals (as classified by Scimago Journal) have been targeted, with the following exceptions that have not been published in Q1/Q2 journals (determined case by case): (a) scientific works essential to discussion on $\mathrm{Hg}$ contamination, (b) related articles in Russian published in local scientific journals and/or university bulletins, (c) limited selected studies with high relevance yet published in third (Q3) quartile journals or below, and (d) pertinent legal documentation regardless of their publication date. 


\section{Human Exposure to $\mathrm{Hg}$, Regulations on $\mathrm{Hg}$, and $\mathrm{Hg}$ Mobility}

\subsection{Human Exposure to Mercury, Regulations}

$\mathrm{Hg}$ is classified as one of 13 priority hazardous substances according to the adopted Water Framework Directive and the Environmental Quality Standards Directive [23,24]. Ingestion of contaminated products, water, vegetables grown on the polluted sites, inhalation, dermal contact, as well as pica-behavior of children (ingestion of non-edible objects such as soil) are the main exposure pathways [16,17]. The consumption of fish from $\mathrm{Hg}$-contaminated sources is the main route of exposure to $\mathrm{MeHg}$ [25-27]. It is considered to be the most toxic form of $\mathrm{Hg}$ due to its increased retention by organisms at various levels of the food chain [28]. The sensitive groups, including the fetus, newborn, and children, are most susceptible to Hg exposure's harmful effects on the nervous system, kidneys, and fetuses $[2,16]$. These effects are mainly dependent on the exposure pathway, duration, and concentration [29].

Different forms of $\mathrm{Hg}$ have varying human toxicity and bioavailability, strongly dependent on the route of exposure [18]. Elemental $\mathrm{Hg}$ is much more dangerous when inhaled (due to a high vapor pressure) than being ingested, as it has low gastrointestinal absorption, but it can easily penetrate lung tissue and enter the blood system [18]. On the other hand, inorganic $\mathrm{Hg}$ (e.g., $\mathrm{HgCl}_{2}$ ) and organic $\mathrm{Hg}$ (via food, mostly fish) are more harmful when ingested, and organic $\mathrm{Hg}$ has up to $95 \%$ bioavailability through the gastrointestinal tract $[16,30]$. Finally, the dermal absorption of all three forms of $\mathrm{Hg}$ is still unclear, and elemental $\mathrm{Hg}$ and $\mathrm{HgCl}_{2}$ have some potentials for dermal uptake [16]. Although dermal exposure to contaminated sites has generally received less attention than oral and inhalation exposures due to limited exposure scenarios and less perceived potential for toxicity, the risk can still be significant for specific contaminants and scenarios [31]. U.S. Environmental Protection Agency (U.S. EPA) introduced the Reference Concentration for Inhalation Exposure for elemental $\mathrm{Hg}$ $\left(3 \times 10^{-4} \mathrm{mg} / \mathrm{m}^{3}\right)$. It is marked as non-classifiable as to human carcinogenicity (Class D) [32], whereas the Agency for Toxic Substances and Disease Registry [30] set the minimum risk level for chronic exposure to elemental $\mathrm{Hg}$ via inhalation at $0.0002 \mathrm{mg} / \mathrm{m}^{3}$. U.S. EPA has also established a Reference Dose for Oral Exposure (RfD) of $3 \times 10^{-4} \mathrm{mg} / \mathrm{kg}$ - $\mathrm{d}$ for mercuric chloride $\left(\mathrm{HgCl}_{2}\right)$ and identified it as a possible carcinogen (Class C) [33]. MeHg has RfD of $1 \times 10^{-4} \mathrm{mg} / \mathrm{kg}$-d (U.S. EPA 2001) and minimum risk level for chronic ingestion of $0.0003 \mathrm{mg} / \mathrm{kg}-\mathrm{d}$ [30]. It has been identified as possibly carcinogenic to humans (Class C) [34]. The provisional tolerable daily intake of $5 \mu \mathrm{g} / \mathrm{kg}$ of body weight for total $\mathrm{Hg}$ with a maximum of $3.3 \mu \mathrm{g}(\mathrm{MeHg}) / \mathrm{kg}$ of body weight as a general guideline was recommended [14]. Different bioavailabilities, toxicity levels, and effects of $\mathrm{Hg}$ forms make speciation of $\mathrm{Hg}$ essential during the risk assessment of $\mathrm{Hg}$-contaminated sites.

To prevent human exposure to $\mathrm{Hg}$ and protect the population and the environment, governments and health protection agencies worldwide have established maximum allowable levels of $\mathrm{Hg}$ in different media (Table 1, including maximum permissible concentration (MPC) standards for Kazakhstan). The Kazakh standards regulating Hg levels in soils are comparable to others, but $\mathrm{Hg}$ limits for air and water are more stringent than those proposed by the World Health Organization (WHO), European Council (EC), and governments of the U.S. and Canada, setting an ambitious goal to achieve. Moreover, in some cases, e.g., to reduce atmospheric Hg concentrations, while countries like Kazakhstan set maximum allowable concentrations, others, including the U.S., Canada, and the EU region, opt for regulations controlling the $\mathrm{Hg}$ emissions instead. 
Table 1. Maximal permissible concentrations of mercury.

\begin{tabular}{|c|c|c|c|c|c|}
\hline Medium & $\begin{array}{l}\text { World Health } \\
\text { Organization }\end{array}$ & USA & Canada & E.U. & Kazakhstan \\
\hline $\begin{array}{l}\text { In air within working } \\
\text { zones }\left(\mu \mathrm{g} / \mathrm{m}^{3}\right)\end{array}$ & $\begin{array}{l}\text { not available } \\
\text { (n.a.) }\end{array}$ & $\begin{array}{l}100(8 \mathrm{~h} \text { and } \\
\text { ceiling) [29] }\end{array}$ & (n.a.) & $\begin{array}{c}\text { elemental and } \\
\text { inorganic, Sweden: } \\
30(8 \mathrm{~h}) \\
\text { organic: } 10(8 \mathrm{~h})[5]\end{array}$ & $5[35]$ \\
\hline $\begin{array}{l}\text { In ambient air of } \\
\text { populated areas } \\
\left(\mu \mathrm{g} / \mathrm{m}^{3}\right)\end{array}$ & 1 (annual) [36] & (n.a.) & (n.a.) & (n.a.) & $0.3[35]$ \\
\hline $\begin{array}{l}\text { In water for sanitary } \\
\text { and domestic use } \\
\qquad(\mu \mathrm{g} / \mathrm{L})\end{array}$ & 1 [14] & $\begin{array}{l}2 \text { (maximum } \\
\text { contaminant } \\
\text { level) [37] }\end{array}$ & $1[38]$ & $\begin{array}{c}\text { drinking water: } 1 \\
\text { (parametric value) [39] } \\
\text { surface waters: } 0.07 \\
\text { (maximum } \\
\text { contaminant level) [39] }\end{array}$ & $0.5[40]$ \\
\hline $\begin{array}{l}\text { In soil for } \\
\text { agricultural use and } \\
\text { in residential places } \\
(\mathrm{mg} / \mathrm{kg} \text { of soil })\end{array}$ & (n.a.) & $\begin{array}{c}\text { California: } 1 \\
\text { [41] }\end{array}$ & $6.6[42]$ & Netherlands: 0.83 [43] & $2.1[44]$ \\
\hline $\begin{array}{l}\text { In soil of other areas } \\
\text { (mg/kg of soil) }\end{array}$ & (n.a.) & $\begin{array}{c}\text { industrial, } \\
\text { California: } 4.4 \\
{[41]}\end{array}$ & $\begin{array}{c}\text { industrial: } 50 \\
\text { [42] }\end{array}$ & $\begin{array}{c}\text { industrial, } \\
\text { Netherlands: } 4.8 \text { [43] }\end{array}$ & $10[44]$ \\
\hline $\begin{array}{l}\text { In biota }(\mathrm{mg} / \mathrm{kg} \text { wet } \\
\text { weight) }\end{array}$ & $\begin{array}{l}\text { fish: } 0.5 \\
\text { (MeHg) } \\
\text { predatory fish: } \\
1 \text { (MeHg) [45] }\end{array}$ & $1(\mathrm{MeHg})[45]$ & $\begin{array}{c}\text { all fish except } \\
\text { shark, } \\
\text { swordfish and } \\
\text { tuna: } 0.5[45]\end{array}$ & $\begin{array}{c}\text { fish: } 0.5 \\
\text { predatory fish: } 1 \text { [45] }\end{array}$ & $\begin{array}{l}\text { fish: } 0.3 \\
\text { predatory } \\
\text { fish: } 0.6[46]\end{array}$ \\
\hline
\end{tabular}

\subsection{Effect of Site-Specific Conditions on Hg Mobility}

$\mathrm{Hg}$ is generally immobile in soils because of its extremely high affinity to organic matter and sulfur ligands [13]. Hence, elevated but immobile $\mathrm{Hg}$ concentrations are usually associated with soils with high organic content. However, $\mathrm{Hg}$ can be released into the atmosphere at high-temperature conditions (Figure 2) [47]. It was also suggested that mostly immobile $\mathrm{Hg}$ fraction bonds to coarse-grain-sized soil particles, which only becomes mobile during the flooding period [48]. Under anaerobic conditions, the microbial reduction of sulfates might take place in soils resulting in the formation of $\mathrm{Hg}$ sulfide (HgS, known as cinnabar), which is a chemically stable and highly insoluble form of $\mathrm{Hg}$.

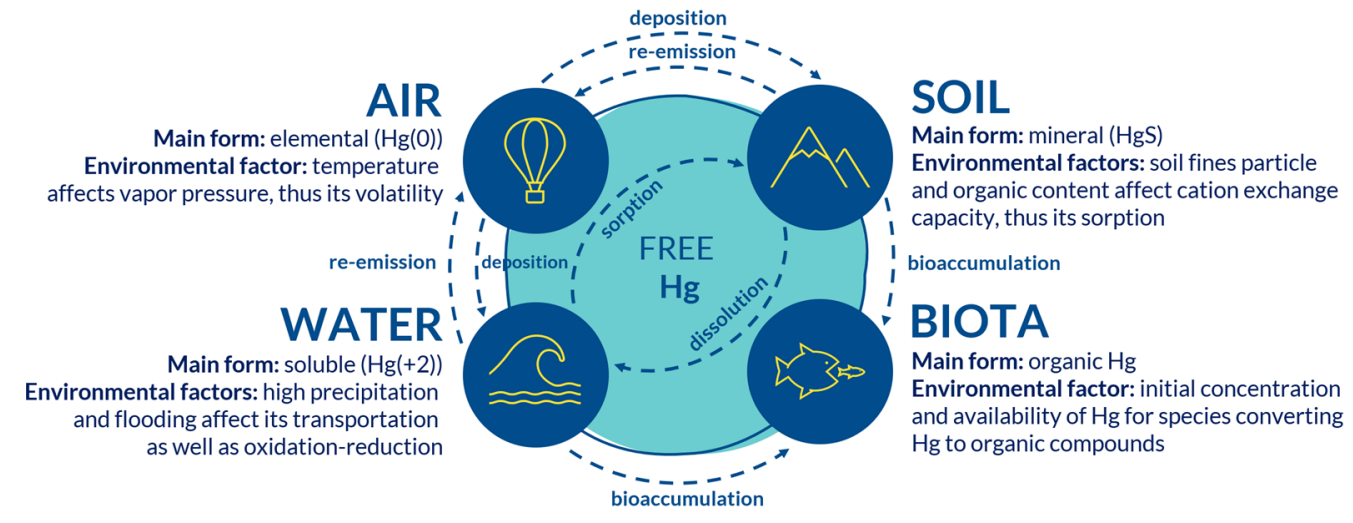

Figure 2. Main forms of $\mathrm{Hg}$ and environmental factors affecting $\mathrm{Hg}$ presence in different media.

$\mathrm{Hg}$ adsorption also differs in soil types, and the highest sorption of low-mobility $\mathrm{Hg}$ is attributed to the finest size fraction, e.g., in clay, loams, and sands [13]. Hg sorption is also attributed to the elevated specific surface area and cation exchange capacity in clays [49]. Water-soluble and highly mobile $\mathrm{Hg}$ fraction is significantly correlated with total organic carbon content in the soil, assuming that total organic carbon binds the mobile forms of $\mathrm{Hg}$ [13]. 
As natural conditions on a contaminated site have a strong influence on the content and migration of chemicals in the environment, it is essential to be informed about site-specific parameters. The climate of Central and North Kazakhstan regions is classified as an extreme continental climate with strong winds, sharp seasonal changes between cold winters (average temperature of $-15^{\circ} \mathrm{C}$ in January), and warm summers (average temperature of $+20^{\circ} \mathrm{C}$ in July) [22,50,51]. Low annual precipitation (e.g., $250 \mathrm{~mm}$ ) and much higher potential evaporation (e.g., $1000 \mathrm{~mm}$ ) values indicate the semi-arid climate's characteristics. Melting snow is the main water supply for most of the area's rivers and surface water bodies, and it is typical to have annual spring floodings followed by subsequent drainage in summer [22]. Moreover, the difference between diurnal and nocturnal temperatures in the region might easily exceed $20^{\circ} \mathrm{C}$ [51]. The vegetation consists mainly of grass with more vibrant plant growth along the riverbanks and planes flooded in spring.

According to soil maps developed by the Food and Agriculture Organization of the United Nations, most soils in Northeast Kazakhstan (including Pavlodar and the surroundings of Nura River) are classified as Kastanozems [52]. Kastanozems have relatively high humus and calcium ions content and are used primarily for agricultural purposes [53]. Hg's high affinity to soils' organic content impedes its mobility, and the spread and transport of $\mathrm{Hg}$ from contaminated soils to groundwater is expected to be low in the region's Kastanozems. In addition, limited areas of the region and the Nura River's riverbed soils are classified as Solonetz and Gleysols, respectively [52]. Moreover, low temperatures, as well as snow cover during long winters in the area, inhibit the volatilization of $\mathrm{Hg}$ and its escape to the atmosphere. However, dry and warm weather with strong winds in the steppes during the summer season might contribute to atmospheric re-emission and long-range transport of $\mathrm{Hg}$. Finally, low annual precipitation prevents solubilization of soil-bound $\mathrm{Hg}$ except for annual flooding episodes. These episodes (in addition to increasing soil's moisture content) might erode some portion of the soil and transport $\mathrm{Hg}$ containing soil particles. Based on the climate and environmental characteristics of North and Central Kazakhstan, $\mathrm{Hg}$ contamination in this region is expected to be primarily localized due to relatively low mobilization, solubilization, and volatilization of $\mathrm{Hg}$.

The following sections review the Hg contamination in two sites in Kazakhstan: a chlor-alkali plant impacting the area around Lake Balkyldak and Pavlodar Region (Site \#1), and an acetaldehyde plant impacting the area around Nura River and Temirtau Region (Site \#2). A summary of the studies investigating these regions (Table 2), the comparison between these two sites (Table 3), and similar sites from the literature (Table 4 ) are provided in the tabular forms. 
Table 2. Summary of literature on $\mathrm{Hg}$ contamination in Kazakhstan.

\begin{tabular}{|c|c|c|c|c|c|c|c|}
\hline Study & Title & Objective & Sampling & Analysis & Main Findings & Conclusions & Recommendations \\
\hline $\begin{array}{l}2000 a \\
\text { Heaven } \\
\text { et al. [54] }\end{array}$ & $\begin{array}{l}\text { Mercury in the } \\
\text { River Nura and } \\
\text { its floodplain, } \\
\text { Central } \\
\text { Kazakhstan: I. } \\
\text { River sediments } \\
\text { and water }\end{array}$ & $\begin{array}{l}\text { Establish the } \\
\text { location, extent, } \\
\text { and nature of the } \\
\text { contaminated } \\
\text { sediments and } \\
\text { evaluate the } \\
\text { potential for } \\
\text { sediment transport } \\
\text { in the Nura river }\end{array}$ & $\begin{array}{l}\text { River sediments } \\
(\mathrm{n}=156) ; \text { water } \\
(\mathrm{n}=\mathrm{n} / \mathrm{a}) ; \\
\text { Surveying of the } \\
\text { riverbed and } \\
\text { backwaters with } \\
\text { sediments } \\
\text { thickness }\end{array}$ & $\begin{array}{l}\text { Sediments: acid } \\
\text { digestion + } \\
\text { CV-AAS; } \\
\text { Water (on site): } \\
\mathrm{Au} \\
\text { pre-concentration } \\
\text { and } \mathrm{SnCl}_{2} \\
\text { reduction + } \\
\text { portable AAS }\end{array}$ & $\begin{array}{l}\text { Sediments: very high } \\
\text { concentrations in first } \\
15 \mathrm{~km} \text { downstream, average } \\
150-240 \mathrm{mg} / \mathrm{kg} \text {; } \\
\text { Estimated total silts between } \\
\text { Temirtau and Intumak Reservoir } \\
(75 \mathrm{~km}) 463,500 \mathrm{~m}^{3} \text { or } 9.4 \mathrm{t} \mathrm{Hg} \text {; } \\
\text { A major part of polluted } \\
\text { sediment not transported far } \\
\text { downstream (except for floods) } \\
\mathrm{Hg} \text { in backwaters reflect changes } \\
\text { of } \mathrm{Hg} \text { in riverbed silts, in first } \\
5-15 \mathrm{~km} \text { average } 86 \mathrm{mg} / \mathrm{kg} \text {, } \\
\text { falling to } 2.6 \mathrm{mg} / \mathrm{kg} \text { near Intumak } \\
\text { Water: mean }<1 \text { } \mu \mathrm{g} / \mathrm{L} \text { (EU limit } \\
\text { for inland surface waters \& WHO } \\
\text { (1984) in drinking water); but }> \\
0.3 \mu \mathrm{L} / \mathrm{L} \text { local limit for } \\
\text { fish-inhabited waters; } \\
\text { No general relationship between } \\
\text { amount of suspended particulate } \\
\text { matter (SPM) and total, dissolved } \\
\text { or suspended Hg }\end{array}$ & $\begin{array}{l}\text { Results were lower } \\
\text { than expected; } \\
\text { most of the } \\
\text { contaminated silts } \\
\text { do not appear to be } \\
\text { readily transported } \\
\text { for long distances } \\
\text { downstream (also } \\
\text { confirmed by } \\
\text { hydraulic modeling } \\
\text { work (not } \\
\text { presented)); } \\
\text { Hg in the water } \\
\text { leaving the reservoir } \\
\text { would suggest that } \\
\text { more than } \\
\text { 100-200 kg Hg/year } \\
\text { could be moving } \\
\text { downstream (mainly } \\
\text { dissolved form) }\end{array}$ & $\begin{array}{l}\text { The desired option } \\
\text { for reclamation is to } \\
\text { dredge silts from the } \\
\text { outfall canal and } \\
\text { remove highly } \\
\text { polluted sediments } \\
\text { from its banks; } \\
\text { dredge technogenic } \\
\text { silts from the first } \\
25-30 \mathrm{~km} \text { of } \\
\text { riverbed below } \\
\text { Temirtau and limit } \\
\text { further distribution; } \\
\text { remove silts with } \\
>10 \text { mg/kg Hg } \\
\text { deposited on banks } \\
\text { Management of } \\
\text { discharge: to reduce } \\
\text { flood size and } \\
\text { prevent disturbance } \\
\text { of sediment }\end{array}$ \\
\hline
\end{tabular}


Table 2. Cont

\begin{tabular}{|c|c|c|c|c|c|c|c|}
\hline Study & Title & Objective & Sampling & Analysis & Main Findings & Conclusions & Recommendations \\
\hline $\begin{array}{l}2000 b \\
\text { Heaven } \\
\text { et al. [55] }\end{array}$ & $\begin{array}{l}\text { Mercury in the } \\
\text { River Nura and } \\
\text { its floodplain, } \\
\text { Central } \\
\text { Kazakhstan: II. } \\
\text { Floodplain soils } \\
\text { and riverbank } \\
\text { silt deposits }\end{array}$ & $\begin{array}{l}\text { A detailed survey } \\
\text { of the floodplain to } \\
\text { investigate the } \\
\text { extent of pollution } \\
\text { and to assess the } \\
\text { need for } \\
\text { remediation }\end{array}$ & $\begin{array}{l}\text { A survey covering } \\
160 \mathrm{~km} 2 \text { of the } \\
\text { floodplain of River } \\
\text { Nura (72 lakes in } \\
\text { total); } \\
\text { Topsoil samples } \\
0-15 \mathrm{~cm}(\mathrm{n}=1100) ; \\
\text { Silts at } \\
\text { highly-contaminated } \\
\text { Zhaur Swamp } \\
(\mathrm{n}=157 \text { from } 28 \\
\text { boreholes); } \\
\text { Additional soil } \\
\text { samples from } \\
\text { irrigated areas in } \\
\text { 1998 }(\mathrm{n}=10)\end{array}$ & $\begin{array}{l}\text { Acid digestion }+ \\
\text { AAS } \\
\text { Silts-preliminary } \\
\text { sequential } \\
\text { extraction tests: } \\
0.1 \mathrm{M} \mathrm{HCl}\end{array}$ & $\begin{array}{l}\text { Topsoils ( } 53 \mathrm{t} \mathrm{Hg} \text { ): from } 0.01 \text { to } \\
>100 \mathrm{mg} / \mathrm{kg} \text {, } \\
\mathrm{Hg}>21 \mathrm{mg} / \mathrm{kg} \text { (tenfold local } \\
\text { limit) mainly in first } 25 \mathrm{~km} \text { of } \\
\text { river, > } 10 \mathrm{mg} / \mathrm{kg} \text { (Dutch } \\
\text { intervention value) up to } \\
60 \mathrm{~km} \text { downstream, } \\
\text { River bank deposits } / \mathrm{silts} \text { ( } 65 \mathrm{t} \\
\mathrm{Hg} \text { ): mean } 73.3 \mathrm{mg} / \mathrm{kg} \text { in most } \\
\text { contaminated section; mean } \\
13.4 \mathrm{mg} / \mathrm{kg} 70 \mathrm{~km} \text { downstream } \\
\text { Zhaur swamp formerly used as } \\
\text { waste disposal area ( } 62 \mathrm{t} \mathrm{Hg):} \mathrm{up} \\
\text { to } 1974 \mathrm{mg} / \mathrm{kg} \text { at the surface; fall } \\
\text { rapidly with increasing depth, } \\
\text { mean total Hg } 306.7 \mathrm{mg} / \mathrm{kg} \text { in } \\
\text { upper } 20 \mathrm{~cm} \\
\text { In older silts w/total Hg } \\
10.2-10.7 \mathrm{mg} / \mathrm{kg} \text { : highly mobile } \\
71.6-87.9 \% \text {, rel. mobile (oxides) } \\
2.1-3.5 \%, \text { insoluble } 7.2-24.6 \% ; \\
\text { In sediment from riverbed below } \\
\text { Intumak with total } 0.017 \mathrm{mg} / \mathrm{kg}: \\
\text { highly mobile } 15.5 \% \text {, relatively } \\
\text { mobile } 10 \% \text {, insoluble } 74.5 \%\end{array}$ & $\begin{array}{l}\text { The contamination is } \\
\text { severe but relatively } \\
\text { localized, with }>70 \% \\
\text { of mercury in } \\
\text { topsoils and }>90 \% \text { of } \\
\text { mercury in } \\
\text { riverbank deposits } \\
\text { located within } \\
25 \mathrm{~km} \text { from the } \\
\text { source. }\end{array}$ & $\begin{array}{l}\text { Removal of the silt } \\
\text { deposits from banks } \\
\text { in the first } \\
30 \mathrm{~km} \text { below outfall } \\
\text { would remove }>90 \% \\
\text { of } \mathrm{Hg} \text {; isolate } \mathrm{Hg} \text { by } \\
\text { stockpiling silts } \\
\text { under a meter of } \\
\text { inert cover material } \\
\text { in a location safe } \\
\text { from groundwater } \\
\text { intrusion and } \\
\text { flooding; cease } \\
\text { cultivation of Zhaur } \\
\text { Swamp; remove and } \\
\text { isolate upper } 40 \mathrm{~cm} \\
\text { of soil; soils with }> \\
10 \text { mg/kg should be } \\
\text { taken out of } \\
\text { agricultural } \\
\text { production; } \\
\text { minimize flooding } \\
\text { of contaminated } \\
\text { areas of the Nura } \\
\text { valley by regulating } \\
\text { the discharge from } \\
\text { Samarkand } \\
\text { Reservoir }\end{array}$ \\
\hline
\end{tabular}


Table 2. Cont

\begin{tabular}{|c|c|c|c|c|c|c|c|}
\hline Study & Title & Objective & Sampling & Analysis & Main Findings & Conclusions & Recommendations \\
\hline $\begin{array}{l}2000 \\
\text { Yanin } \\
{[56]}\end{array}$ & $\begin{array}{l}\text { Mercury in the } \\
\text { epiphyte } \\
\text { retained of the } \\
\text { Nura River } \\
\text { (Kazakhstan) as } \\
\text { an indicator of } \\
\text { technogenic } \\
\text { pollution. }\end{array}$ & $\begin{array}{l}\text { To evaluate the } \\
\text { effectiveness of } \\
\text { epiphytic } \\
\text { suspension in } \\
\text { assessing the level } \\
\text { and scale of } \\
\text { waterbodies } \\
\text { pollution by } \\
\text { mercury }\end{array}$ & $\begin{array}{l}\text { Epiphytic } \\
\text { suspension from } \\
\text { Myrio phyllum } \\
\text { specatum L. (dried } \\
\text { and separated) } \\
\text { Technogenic silts } \\
\text { (dried and sieved) }\end{array}$ & $\begin{array}{l}\text { AAS } \\
\text { (IMGRE-900 } \\
\text { mercury } \\
\text { analyzer) }\end{array}$ & $\begin{array}{l}\text { Maximum total } \mathrm{Hg} \\
\text { concentrations in technogenic } \\
\text { silts near wastewater discharge } \\
\text { (about } 6-10 \mathrm{~km} \text { ); } \\
0.05 \mathrm{~km} \text { from outfall mean total } \\
\mathrm{Hg} \text { in silts } 33.54 \mathrm{mg} / \mathrm{kg} \text {, } \\
10 \mathrm{~km} \text { away mean } \mathrm{Hg} \text { is } \\
\text { maximum } 47.62 \mathrm{mg} / \mathrm{kg} \text {; } \\
\mathrm{Hg} \text { in technogenic silts > } \mathrm{Hg} \text { in } \\
\text { epipihtytes; epyphytes can be } \\
\text { used as an indicator }\end{array}$ & $\begin{array}{l}\text { Epiphyte suspension } \\
\text { (which intensively } \\
\text { concentrates } \mathrm{Hg} \text { ) } \\
\text { reflects the influence } \\
\text { of various } \mathrm{Hg} \\
\text { sources to } \\
\text { watercourses and } \\
\text { shows the extent of } \\
\text { pollution. } \\
\mathrm{Hg} \text { in technogenic } \\
\text { silts is mostly } \\
\text { deposited in the } \\
\text { vicinity of the } \\
\text { wastewater } \\
\text { discharge }\end{array}$ & $\begin{array}{l}\text { It is proposed to use } \\
\text { epiphytic } \\
\text { suspension, i.e., } \\
\text { suspension } \\
\text { precipitated on } \\
\text { macrophytes, to } \\
\text { estimate the level } \\
\text { and scale of the } \\
\text { technogenic } \\
\text { pollution of Hg's } \\
\text { rivers. }\end{array}$ \\
\hline
\end{tabular}


Table 2. Cont

\begin{tabular}{|c|c|c|c|c|c|c|c|}
\hline Study & Title & Objective & Sampling & Analysis & Main Findings & Conclusions & Recommendations \\
\hline $\begin{array}{l}2007 b \\
\text { Ullrich et } \\
\text { al. [57] }\end{array}$ & $\begin{array}{l}\text { Mercury } \\
\text { distribution and } \\
\text { transport in a } \\
\text { contaminated } \\
\text { river system in } \\
\text { Kazakhstan and } \\
\text { associated } \\
\text { impacts on } \\
\text { aquatic biota }\end{array}$ & $\begin{array}{l}\text { To investigate the } \\
\text { transport, fate, and } \\
\text { bioavailability of } \\
\mathrm{Hg} \text { in the Nura } \\
\text { river system by } \\
\text { analyzing } \\
\text { sediments, water, } \\
\text { plants, and fish } \\
\text { sampled from the } \\
\text { river system }\end{array}$ & $\begin{array}{l}\text { Sediments from } \\
\text { different years, } \\
\text { locations, and } \\
\text { depths along the } \\
\text { river; water, } \\
\text { unfiltered and } \\
\text { filtered }(0.45 \mu \mathrm{m}) \text {; } \\
\text { plants (cattail and } \\
\text { reed); fish from the } \\
\text { river, lakes, local } \\
\text { market }(\mathrm{n}=130 \text {, } \\
20,6)\end{array}$ & $\begin{array}{l}\text { Sediments: acid } \\
\text { digestion + } \\
\text { CV-AAS } \\
\text { (Perkin-Elmer } \\
\text { AAnalyst 100), } \\
\text { acid digestion + } \\
\text { CV-AFS, } \\
\text { MeHg_modified } \\
\text { Westöö } \\
\text { procedure, } \\
\text { GC-ECD; water: } \\
\text { total Hg and } \\
\text { suspended } \\
\text { solids-BrCl, } \\
\text { SnCl } \text { reduction } \\
\text { + CV-AFS } \\
\text { (Millennium } \\
\text { Merlin); plants: } \\
\text { acid digestion + } \\
\text { CV-AAS (), } \\
\text { CV-AFS; fish: } \\
\text { acid digestion + } \\
\text { CV-AFS }\end{array}$ & $\begin{array}{l}\text { Sediments within } \\
20 \mathrm{~km} \text { downstream of } \\
\text { effluent-highly polluted, a } \\
\text { strong source of water } \\
\text { contamination; } \\
\mathrm{THg} \text { in most contaminated } \\
\text { section }=9.95 \text { to } 306 \mathrm{mg} / \mathrm{kg} \text {; } \\
\text { Highest MeHg in surface } \\
\text { sediments }(4.9-39 \mathrm{ug} / \mathrm{kg})<0.1 \% \\
\mathrm{THg} \text {; the significant inverse } \\
\text { relationship between THg and } \\
\text { MeHg\% formed in sediments } \\
\text { Unfiltered surface water during } \\
\text { flood peak THg = } 1600-4300 \mathrm{ng} / \mathrm{L} \\
\text { Background concentrations of Hg } \\
\text { in surface water are not reached } \\
\text { for } 200 \mathrm{~km} \text { downstream, even in } \\
\text { wetlands during flood } \\
\text { In aquatic plants Hg in most } \\
\text { contaminated section }=15-20 \mathrm{x} \\
\text { background; fish impacted for } \\
>125 \mathrm{~km} \text { downstream from the } \\
\text { source- significant transport of } \\
\text { dissolved MeHg to downstream } \\
\text { areas, in situ MeHg production }\end{array}$ & $\begin{array}{l}\text { Elevated Hg } \\
\text { concentrations in } \\
\text { water, fish, and } \\
\text { aquatic plants near } \\
\text { impoundments } \\
\text { appear to indicate } \\
\text { that Hg's availability } \\
\text { for methylation may } \\
\text { be increased in these } \\
\text { areas. } \\
\text { The high } \\
\text { immobilization of } \\
\text { mercury by } \\
\text { industrial sludge, } \\
\text { the basis of which } \\
\text { was the ash of a } \\
\text { thermal power } \\
\text { station, makes } \\
\text { debatable the } \\
\text { rationale for } \\
\text { cleaning up the } \\
\text { mercury-containing } \\
\text { bottom sediments of } \\
\text { the Nura River } \\
\text { under the project of } \\
\text { the International } \\
\text { Bank for } \\
\text { Reconstruction and } \\
\text { Development. }\end{array}$ & $\begin{array}{l}\text { Studies on terminal } \\
\text { wetlands of the } \\
\text { Nura, methylation } \\
\text { capacity at Intumak } \\
\text { and Samarkand } \\
\text { barrage } \\
\text { Prevent further } \\
\text { transport of Hg to } \\
\text { downstream reaches }\end{array}$ \\
\hline
\end{tabular}


Table 2. Cont

\begin{tabular}{|c|c|c|c|c|c|c|c|}
\hline Study & Title & Objective & Sampling & Analysis & Main Findings & Conclusions & Recommendations \\
\hline $\begin{array}{l}2010 a \\
\text { Hsiao et } \\
\text { al. [3] }\end{array}$ & $\begin{array}{l}\text { Burdens of } \\
\text { mercury in } \\
\text { residents of } \\
\text { Temirtau, } \\
\text { Kazakhstan I: } \\
\text { Hair mercury } \\
\text { concentrations } \\
\text { and factors of } \\
\text { elevated hair } \\
\text { mercury levels }\end{array}$ & $\begin{array}{l}\text { To evaluate } \mathrm{Hg} \\
\text { exposure levels } \\
\text { through } \\
\text { concentrations in } \\
\text { hair of the local } \\
\text { population; to } \\
\text { describe the } \\
\text { relationship } \\
\text { between } \mathrm{Hg} \\
\text { concentrations in } \\
\text { hair and dietary } \\
\text { intake and other } \\
\text { factors; to identify } \\
\text { group at high risk } \\
\text { of Hg exposure }\end{array}$ & $\begin{array}{l}\text { Hair from } \\
\text { Temirtau and } \\
\text { Almaty ( } \mathrm{n}=289 \\
\text { and 13), fish } \\
\text { purchased or } \\
\text { caught locally } \\
(\mathrm{n}=111) \text {, food } \\
\text { (veg, milk, beef) } \\
(\mathrm{n}=24)\end{array}$ & $\begin{array}{l}\text { Hair: Rigaku } \\
\text { Mercury } \\
\text { Analyzer SP-3 or } \\
\text { MA-2; fish, food: } \\
\text { acid digestion + } \\
\text { CV-AFS } \\
\text { (Millennium } \\
\text { Merlin) }\end{array}$ & $\begin{array}{l}\mathrm{Hg} \text { in hair }=0.009-5.184 \mu \mathrm{g} / \mathrm{g} \text {, } \\
\text { mean } 0.577 \mu \mathrm{g} / \mathrm{g} \text {; in } ~ 17 \% \text { of } \\
\text { population }>1 \mu \mathrm{g} / \mathrm{g} \\
\text { A positive correlation between } \\
\mathrm{Hg} \text { in hair and frequencies of } \\
\text { river fish consumption } \\
\text { Subgroups of males, people }>45 \\
\text { y.o and fishermen or } \\
\text { anglers-elevated levels }\end{array}$ & $\begin{array}{l}\text { The mean } \\
\text { concentration of } \mathrm{Hg} \\
\text { in the river fish } \\
\text { being } 0.43 \mu \mathrm{g} / \mathrm{g} \text { and } \\
\text { an average } \\
\text { bodyweight of } 67 \mathrm{~kg} \\
\text { of the local people; } \\
\mathrm{Hg} \text { in hair at a } \\
\text { moderate level, } \\
\text { exposure levels not } \\
\text { very severe }\end{array}$ & $\begin{array}{l}\text { Raise awareness of } \\
\text { the dangers of } \\
\text { consuming fish } \\
\text { caught in River } \\
\text { Nura and its oxbow } \\
\text { lakes below } \\
\text { Temirtau, or at least } \\
\text { decrease } \\
\text { consumption rate to } \\
\text { no more than once a } \\
\text { week, especially for } \\
\text { pregnant women }\end{array}$ \\
\hline $\begin{array}{l}2010 b \\
\text { Hsiao et } \\
\text { al. [21] }\end{array}$ & $\begin{array}{l}\text { Burdens of } \\
\text { mercury in } \\
\text { residents of } \\
\text { Temirtau, } \\
\text { Kazakhstan. II: } \\
\text { Verification of } \\
\text { methodologies } \\
\text { for estimating } \\
\text { human exposure } \\
\text { to high levels of } \\
\text { Hg pollution in } \\
\text { the environment }\end{array}$ & $\begin{array}{l}\text { To evaluate the } \\
\text { exposure risk } \\
\text { posed by Hg waste } \\
\text { from a disused } \\
\text { acetaldehyde plant } \\
\text { at Temirtau, to } \\
\text { identify the } \\
\text { adaptability of } \\
\text { these approaches, } \\
\text { and discuss the } \\
\text { uncertainty and } \\
\text { variability } \\
\text { generating in the } \\
\text { methodologies of } \\
\text { exposure } \\
\text { assessments }\end{array}$ & $\begin{array}{l}\text { Fish }(\mathrm{n}=21) \text {, food } \\
\text { (vegetables, milk, } \\
\text { beef }(\mathrm{n}=24) \text {, soils } \\
(\mathrm{n}=27), \text { loose dust } \\
(\mathrm{n}=38), \text { hair } \\
(\mathrm{n}=289) ; \\
\text { questionnaire } \\
(\mathrm{n}=232)\end{array}$ & $\begin{array}{l}\text { Fish, food: acid } \\
\text { digestion + } \\
\text { CV-AFS } \\
\text { (Millennium } \\
\text { Merlin), soil and } \\
\text { dust: acid } \\
\text { digestion + } \\
\text { CV-AAS } \\
\text { (Perkin-Elmer } \\
\text { AAnalyst 100), } \\
\text { hair: Rigaku } \\
\text { Mercury } \\
\text { Analyzer SP-3 or } \\
\text { MA-2; } \\
\text { HQ = Average } \\
\text { daily intake/RfD }\end{array}$ & $\begin{array}{l}\text { Probabilistic (Monte-Carlo): ADD } \\
\text { of MeHg mean } 0.08(0.003-12.233 \text { ) } \\
\mu \mathrm{g} / \mathrm{kg} \text { body weight } / \mathrm{day}-75 \% \text { of } \\
\mathrm{MeHg} \text { intake via fish; } 19 \% \\
\text { population exceeded } 0.1 \mathrm{ug} / \mathrm{kg} \\
\text { BW/day } \\
\text { Non-carcinogenic risk due to } \\
\text { MeHg contamination: } \mathrm{HI}=0.36 \\
\text { at } 50 \text { percentile, but } \mathrm{HI}=2.53 \text { at } \\
95 \text { percentile } \\
\text { Deterministic: } \mathrm{HI}=\mathrm{sum} \text { of } \\
\mathrm{HQ}=7.92 \text {, where } \mathrm{HQ}=7.62 \text { from } \\
\text { fish consumption }\end{array}$ & $\begin{array}{l}\text { The probabilistic } \\
\text { approach (MC } \\
\text { simulation) is } \\
\text { slightly } \\
\text { overestimated, but } \\
\text { the stable and } \\
\text { reliable prediction } \\
\text { for the high-end } \\
\text { exposed population, } \\
\text { while the } \\
\text { deterministic } \\
\text { approach } \\
\text { overestimated ADD } \\
1.5 \text { times than values } \\
\text { derived from hair. } \\
\text { Fish and shellfish } \\
\text { consumption-major } \\
\text { route of MeHg } \\
\text { exposure }\end{array}$ & $\begin{array}{l}\text { Probabilistic } \\
\text { approach robust, } \\
\text { useful, and reliable } \\
\text { in assessing accurate } \\
\text { levels of exposure } \\
\text { to } \mathrm{Hg}\end{array}$ \\
\hline
\end{tabular}


Table 2. Cont

\begin{tabular}{|c|c|c|c|c|c|c|c|}
\hline Study & Title & Objective & Sampling & Analysis & Main Findings & Conclusions & Recommendations \\
\hline $\begin{array}{l}2002 \\
\text { Ilyushchenko } \\
\text { et al. [58] }\end{array}$ & $\begin{array}{l}\text { Mercury }(\mathrm{Hg}) \\
\text { contamination of } \\
\text { fish fauna of } \\
\text { Balkyldak } \\
\text { technical pond }\end{array}$ & $\begin{array}{l}\text { To investigate the } \\
\text { extent of mercury } \\
\text { contamination in } \\
\text { the fish fauna of } \\
\text { the Balkyldak lake }\end{array}$ & $\begin{array}{l}\text { Fish from } \\
\text { Balkyldak }(\mathrm{n}=55) \text { : } \\
\text { tench, common } \\
\text { perch, silver } \\
\text { crucian carp, } \\
\text { Siberian dace }\end{array}$ & $\begin{array}{l}\text { Acid, } \\
\text { bromide-bromate } \\
\text { digestion }+ \\
\text { CV-AFS (PSA } \\
10.025 \\
\text { Millennium-Merlin) }\end{array}$ & $\begin{array}{l}\text { In } 50 \text { out of } 55 \mathrm{Hg} \text { in muscle } \\
\text { tissue }>0.3 \mathrm{mg} / \mathrm{kg} \text { (max } \\
\text { allowable concentration in } \\
\text { dace/crucian carp/tench) } \\
\text { Average total } \\
\mathrm{Hg}=4.36 / 3.18 / 1.98\end{array}$ & $\begin{array}{l}\text { Limited sample } \\
\text { size does not allow } \\
\text { to draw exact } \\
\text { conclusions }\end{array}$ & $\begin{array}{l}\text { Further research of } \\
\mathrm{Hg} \text { accumulation } \\
\text { in other aquatic } \\
\text { organisms and } \mathrm{Hg} \\
\text { migration along } \\
\text { the food chains of } \\
\text { the ecosystem of } \\
\text { Balkyldak } \\
\text { (hydrobiological } \\
\text { and trophological } \\
\text { research methods) }\end{array}$ \\
\hline $\begin{array}{l}2004 \\
\text { Woodruff } \\
\text { and Dack } \\
{[19]}\end{array}$ & $\begin{array}{l}\text { Analysis of risk } \\
\text { from mercury } \\
\text { contamination at } \\
\text { the Khimprom } \\
\text { Plant in } \\
\text { Kazakhstan }\end{array}$ & $\begin{array}{l}\text { To examine } \\
\text { mercury } \\
\text { contamination at } \\
\text { the chlor-alkali } \\
\text { plant at Pavlodar } \\
\text { and to establish } \\
\text { whether risks to } \\
\text { human health exist } \\
\text { from this } \\
\text { contamination via } \\
\text { vegetable } \\
\text { consumption and } \\
\text { soil ingestion }\end{array}$ & $\begin{array}{l}\text { Surface soils from } \\
\text { site and } \\
\text { Pavlodarskoye } \\
\text { village, } \\
\text { groundwater } \\
\text { (n = unknown) }\end{array}$ & $\begin{array}{l}\text { Risk assessment } \\
\text { (ingestion of food } \\
\text { and soil): (1) UK } \\
\text { Contaminated } \\
\text { Land Exposure } \\
\text { Assessment } \\
\text { (CLEA) model; (2) } \\
\text { The Netherlands, } \\
\text { Van Hall Institute } \\
\text { Risc-Human } \\
\text { Model Version } 3.0\end{array}$ & $\begin{array}{l}\mathrm{Hg} \text { in soil from plant far and } \\
\text { close to contaminated zones } \\
(1997-8 \text { and 2001-2) }=0.0067 \\
\text { and } 835.9 \mathrm{mg} / \mathrm{kg} \text { respectively; } \\
\mathrm{Hg} \text { in soil from Pavlodarskoye } \\
\text { village }(2001-2)=1.5 \mathrm{mg} / \mathrm{kg} ; \\
\mathrm{Hg} \text { in groundwater from plant } \\
(1997-8 \text { and 2001-2) = } 0.00022 \\
\text { and } 18 \mathrm{mg} / \mathrm{L} \text {, respectively; } \mathrm{Hg} \\
\text { in groundwater from } \\
\text { Pavlodarskoye village } \\
\text { (2001-2) }=0.005 \mathrm{mg} / \mathrm{L} ; \\
\mathrm{CLEA} \text { model-vegetable } \\
\text { uptake and ingestion of soil on } \\
\text { vegetables; risk not related to } \\
\text { increased Hg concentrations in } \\
\text { the latter years } \\
\text { Risc-Human model-ingestion } \\
\text { of soil by children, ingestion of } \\
\text { meat and vegetables children } \\
\text { and adults }\end{array}$ & $\begin{array}{l}\text { Possible health } \\
\text { risks to the local } \\
\text { population at } \\
\text { Pavlodarskoye } \\
\text { from the } \\
\text { consumption of } \\
\text { homegrown } \\
\text { vegetable uptake } \\
\text { and with ingestion } \\
\text { of soil attached to } \\
\text { homegrown } \\
\text { vegetables }\end{array}$ & $\begin{array}{l}\text { To obtain a more } \\
\text { representative } \\
\text { value of calculated } \\
\text { risk, factoring in } \\
\text { these differences } \\
\text { recommended that } \\
\text { vegetable uptake } \\
\text { be studied further }\end{array}$ \\
\hline
\end{tabular}


Table 2. Cont

\begin{tabular}{|c|c|c|c|c|c|c|c|}
\hline Study & Title & Objective & Sampling & Analysis & Main Findings & Conclusions & Recommendations \\
\hline $\begin{array}{l}2005 \\
\text { Ilyushchenko } \\
\text { et al. [59] }\end{array}$ & $\begin{array}{l}\text { Activities for } \\
\text { prevention of the } \\
\text { threat of river } \\
\text { Irtysh mercury } \\
\text { pollution in } \\
\text { Pavlodar, } \\
\text { Kazakhstan }\end{array}$ & $\begin{array}{l}\text { Report on the } \\
\text { results and } \\
\text { strategies for } \\
\text { preventing } \\
\text { pollution }\end{array}$ & - & & $\begin{array}{l}\text { Four large hotspots with } \mathrm{Hg} \text { in } \\
\text { soil = }>500 \times 2.1 \mathrm{mg} / \mathrm{kg} \\
2931 \mathrm{~kg} \text { of } \mathrm{Hg} \text { for the industrial site } \\
\text { No.1, } 16,022 \mathrm{~kg} \text { of } \mathrm{Hg} \text { for the area } \\
\text { between the industrial site of former } \\
\mathrm{PO} \text { "Khimprom" and lake Balkyldak; } \\
\text { In the tissue of fish from the lake } \\
0.18-2.2 \mathrm{mg} / \mathrm{kg} \\
\text { The plume of Hg-contaminated } \\
\text { groundwater: up to } 150 \mathrm{ug} / \mathrm{L} \text {, } \\
\text { decreasing with distance from hotspots } \\
\text { In surface water: (i) atmospheric } \\
\text { precipitations in lagoons } \leq 50 \mathrm{mg} / \mathrm{L} \text {; (ii) } \\
\text { surface water to the south from lagoons } \\
3-30 \text { ug/L; (iii) surface water in a ditch } \\
\text { along lake } 2-18 \mathrm{ug} / \mathrm{L} ; \text { (iv) surface water } \\
\text { of lake } 3.4 \mathrm{ug} / \mathrm{L} \text { (near lagoons) to } \\
0.1-0.3 \text { ug/L }(\mathrm{along} \text { the rest of the shore) } \\
\text { In unfinished emergency canal from } \\
\text { the lake to west } \leq 0.01 \text { ug/L; in Irtysh } \\
\text { river }<0.002 \mu \mathrm{g} / \mathrm{L} ; \text { in oxbow lakes near } \\
\text { village }<0.009 \text { ug/L; in predatory fish } \\
\text { from river } 0.075-0.16 \mathrm{mg} / \mathrm{kg}\end{array}$ & $\begin{array}{l}\text { Four scenarios of } \mathrm{Hg} \\
\text { transport with } \\
\text { groundwater until 2030: } \\
\text { (1) direction of plume } \\
\text { does not change-no } \\
\text { severe threat to village } \\
\text { and river; a limited } \\
\text { amount of Hg might } \\
\text { enter the emergency } \\
\text { canal; (2) cut-off wall } \\
\text { around building } 31 ;(3) \\
\text { containment of both } \\
\text { sources of } \\
\text { pollution-eliminate } \\
\text { groundwater } \\
\text { contamination; (4) } \\
\text { changes of } \\
\text { hydrogeological } \\
\text { conditions in the } \\
\text { northern industrial area } \\
\text { of Pavlodar depending } \\
\text { on industrial } \\
\text { development or } \\
\text { degradation }\end{array}$ & $\begin{array}{l}\text { Instead of expensive } \\
\text { and ineffective } \\
\text { recovery of Hg from } \\
\text { highly contaminated } \\
\text { wastes, the } \\
\text { containment } \\
\text { strategy was } \\
\text { proposed assuming } \\
\text { isolation of major } \\
\text { hotspots from the } \\
\text { atmosphere, surface } \\
\text { run-off, and } \\
\text { groundwater. } \\
\text { A cut-off wall } \\
\text { built-in 2003-2005 } \\
\text { around four major } \\
\text { hotspots; topsoil to } \\
0.5 \text { m excavated and } \\
\text { removed to isolated } \\
\text { sites; building } 31 \\
\text { demolished; } \\
\text { monolith storage }\end{array}$ \\
\hline $\begin{array}{l}2006 \text { Panin and } \\
\text { Geldymamedova } \\
\text { [60] }\end{array}$ & $\begin{array}{l}\text { Ecological and } \\
\text { geochemical } \\
\text { characteristics of } \\
\text { soils in Pavlodar, } \\
\text { Republic of } \\
\text { Kazakhstan }\end{array}$ & $\begin{array}{l}\text { To identify the } \\
\text { presence of } \\
\text { heavy metals } \\
\text { and other } \\
\text { chemical } \\
\text { elements in soils } \\
\text { of Pavlodar city }\end{array}$ & $\begin{array}{l}\text { Soil from } \\
\text { Pavlodar and } \\
\text { surrounding } \\
\text { areas }(n=609)\end{array}$ & $\begin{array}{l}\text { Acid } \\
\text { digestion + } \\
\text { AAS (Perkin } \\
\text { Elmer 403 + } \\
\text { HGA-74) }\end{array}$ & $\begin{array}{l}\mathrm{Hg} \text { in the city was in the range of } \\
0.08-18.96 \mathrm{mg} / \mathrm{kg} \\
\text { Mean total Hg in northern industrial } \\
\text { zone } 3.51 \mathrm{mg} / \mathrm{kg} \text {, in the north part of } \\
\text { the city } 0.21 \mathrm{mg} / \mathrm{kg} \\
\text { Mean concentration of elements } \\
1.6-22.5 \text { times higher than background } \\
\text { (especially } \mathrm{Hg} \text {, Cd, Co, Mo) } \\
\text { Northern industrial zone: max } \mathrm{Hg}, \mathrm{V} \text {, } \\
\mathrm{Sr} \text {, Ni compared to other areas } \\
\mathrm{Zc}>128 \text { (ecological disaster area) on } \\
\text { the territory of chemical plant }\end{array}$ & $\begin{array}{l}\text { Maps of the distribution } \\
\text { of chemical elements in } \\
\text { the soils are compiled. } \\
\text { The highest } \\
\text { concentrations of } \\
\text { chemical elements in the } \\
\text { northern industrial zone }\end{array}$ & \\
\hline
\end{tabular}


Table 2. Cont.

\begin{tabular}{|c|c|c|c|c|c|c|c|}
\hline Study & Title & Objective & Sampling & Analysis & Main Findings & Conclusions & Recommendations \\
\hline $\begin{array}{l}\text { 2007a Ullrich } \\
\text { et al. [50] }\end{array}$ & $\begin{array}{l}\text { Mercury } \\
\text { contamination in } \\
\text { the vicinity of a } \\
\text { derelict } \\
\text { chlor-alkali plant. } \\
\text { Part I: Sediment } \\
\text { and water } \\
\text { contamination of } \\
\text { Lake Balkyldak } \\
\text { and the River } \\
\text { Irtysh }\end{array}$ & $\begin{array}{l}\text { To investigate } \\
\text { the impact of } \mathrm{Hg} \\
\text { emissions from } \\
\text { the chlor-alkali } \\
\text { plant on the } \\
\text { surrounding } \\
\text { environment } \\
\text { and, in } \\
\text { particular, the } \\
\text { lake (sediments, } \\
\text { water, and biota) }\end{array}$ & $\begin{array}{l}\text { Sediments } \\
(\mathrm{n}=55) \text { and } \\
\text { water from } \\
\text { Balkyldak } \\
(\mathrm{n}=38) ; \\
\text { sediments and } \\
\text { water from } \\
\text { Irtysh }(\mathrm{n}=32) \text {, } \\
\text { water from } \\
\text { oxbow lakes } \\
(\mathrm{n}=18) ; \text { soil } \\
\text { from } 6 \\
\text { locations } \\
\text { around lake }\end{array}$ & $\begin{array}{l}\text { Acid } \\
\text { digestion + } \\
\text { CV-AAS, } \\
\text { CV-AFS }\end{array}$ & $\begin{array}{l}\mathrm{Hg} \text { in sediments in the lake, near } \\
\text { wastewater outfall pipe up to } \\
1500 \mathrm{mg} / \mathrm{kg} \text {; } \\
\mathrm{Hg} \text { in lake water in the range of } \\
0.11-1.39 \mathrm{ug} / \mathrm{L} \text { (mainly in the southern } \\
\text { part); on windy days, concentration up } \\
\text { to } 7.3 \mathrm{ug} / \mathrm{L} \text {; } \\
\mathrm{Hg} \text { in river sediments up to } \\
0.046 \mathrm{mg} / \mathrm{kg} \text { in the old river channel \& } \\
\text { up to } 0.36 \mathrm{mg} / \mathrm{kg} \text { in floodplain oxbow } \\
\text { lakes; } \\
\mathrm{Hg} \text { in river water-not detected, in } \\
\text { oxbow lakes-trace }(3-9 \mathrm{ng} / \mathrm{L}) \\
\mathrm{Hg} \text { in soil around lake- }-2.65 \mathrm{mg} \mathrm{kg}-1 \\
(0.22-5.72 \mathrm{mg} \mathrm{kg}-1 \text { ) at } 0-10 \mathrm{~cm} \text { depth, } \\
1.81 \mathrm{mg} \mathrm{kg}{ }^{-1} \text { at } 10-20 \mathrm{~cm} \text {, and } 1.14 \mathrm{mg} \\
\mathrm{kg}^{-1} \text { at } 20-50 \mathrm{~cm}\end{array}$ & $\begin{array}{l}\text { Balkyldak sediments are } \\
\text { heavily contaminated. } \\
\text { Thus, the lake poses a } \\
\text { threat and needs } \\
\text { remediation; Hg does } \\
\text { not significantly impact } \\
\text { the Irtysh river } \\
\text { A cut-off wall around } \\
\text { lagoons and clay cover } \\
\text { eliminated a major } \\
\text { source of Hg to the lake. } \\
\text { However, the lake still } \\
\text { receives Hg via an old } \\
\text { outfall pipe }\end{array}$ & $\begin{array}{l}\text { Recommendations: } \\
\text { ex-situ dredging or } \\
\text { disposal; thermal } \\
\text { desorption; capping } \\
\text { and dredging } \\
\text { Preliminary tests } \\
\text { carried out on a } \\
\text { sediment sample } \\
\text { taken from the south } \\
\text { of Lake Balkyldak } \\
\text { indicated that most } \\
\text { Hg was present as } \\
\text { elemental Hg, and } \\
>95 \% \text { of the Hg } \\
\text { could be removed by } \\
\text { ultrasound } \\
\text { (unpublished data). }\end{array}$ \\
\hline $\begin{array}{l}\text { 2007c Ullrich et } \\
\text { al. [61] }\end{array}$ & $\begin{array}{l}\text { Mercury } \\
\text { contamination in } \\
\text { the vicinity of a } \\
\text { derelict } \\
\text { chlor-alkali plant } \\
\text { Part II: } \\
\text { Contamination } \\
\text { of the aquatic } \\
\text { and terrestrial } \\
\text { food chain and } \\
\text { potential risks to } \\
\text { the local } \\
\text { population }\end{array}$ & $\begin{array}{l}\text { To gain a } \\
\text { preliminary } \\
\text { insight into the } \\
\text { potential for } \\
\text { contamination of } \\
\text { the terrestrial } \\
\text { food chain and } \\
\text { the } \\
\text { associatedlevel } \\
\text { of risk. }\end{array}$ & $\begin{array}{l}\text { Water from } \\
\text { lake Balkyldak } \\
(\mathrm{n}=55), \text { from } \\
\text { Irtysh and } \\
\text { oxbow lakes } \\
(\mathrm{n}=30), \text { water } \\
\text { from wells } \\
(\mathrm{n}=30) ; \\
\text { Cow milk from } \\
\text { village }(\mathrm{n}=15), \\
\text { liver and } \\
\text { kidney from } 1 \\
\text { cow; soil } \\
(\mathrm{n}=24)\end{array}$ & $\begin{array}{l}\text { Water: acid } \\
\text { digestion + } \\
\text { CV-AFS }\end{array}$ & $\begin{array}{l}\text { Fish from Balkyldak seriously } \\
\text { contaminated by Hg } \\
\text { (dace>carp }>\text { tench) } \\
\text { Mean (range) } \mathrm{Hg} \text { in perch from } \\
\text { Balkyldak } 0.89(0.16-2.20 \mathrm{mg} / \mathrm{kg})>>> \\
\text { in perch from Irtysh } 0.112 \\
(0.075-0.125 \mathrm{mg} / \mathrm{kg} \text { ) (limited sample } \\
\text { size) } \\
\mathrm{Hg} \text { in } 91 \% \text { of fish exceed the } \\
\text { permissible level } \\
\text { Mean }(\mathrm{range}) \mathrm{Hg} \text { in soil = } 1.04(0.10 \\
\text { and } 3.30) \mathrm{mg} / \mathrm{kg} \\
\mathrm{Hg} \text { in groundwater }<\mathrm{LoD}(5 \mathrm{ng} / \mathrm{L}) \\
\mathrm{Hg} \text { in bovine milk samples }<2 \mathrm{ug} / \mathrm{kg}, \\
\text { tissue }=10.96 \mathrm{ug} / \mathrm{kg}\end{array}$ & $\begin{array}{l}\text { Hg in fish from lake } \\
\text { Balkyldak exceed } \\
\text { current human health } \\
\text { limits; so, consumption } \\
\text { of contaminated fish } \\
\text { appears to be the main } \\
\text { route of exposure for } \\
\text { humans }\end{array}$ & $\begin{array}{l}\text { Eliminate the } \\
\text { current fish } \\
\text { population by using } \\
\text { rotenone (fish } \\
\text { poison) } \\
\text { Environmental and } \\
\text { human health } \\
\text { impacts associated } \\
\text { with cattle grazing } \\
\text { on contaminated } \\
\text { land around the } \\
\text { plant and drinking } \\
\text { contaminated } \\
\text { surface waters } \\
\text { To investigate Hg } \\
\text { uptake from } \\
\text { vegetables grown in } \\
\text { contaminated soil }\end{array}$ \\
\hline
\end{tabular}


Table 2. Cont

\begin{tabular}{|c|c|c|c|c|c|c|c|}
\hline Study & Title & Objective & Sampling & Analysis & Main Findings & Conclusions & Recommendations \\
\hline $\begin{array}{l}2009 \\
\text { Shaimardanova } \\
\text { et al. [62] }\end{array}$ & $\begin{array}{l}\text { Heavy Metals } \\
\text { Accumulation in } \\
\text { Children Hair }\end{array}$ & $\begin{array}{l}\text { To justify the } \\
\text { accumulation } \\
\text { rate of chemicals } \\
\text { (Hg, Zn, Se, } \mathrm{Rb} \text { ) } \\
\text { in children's hair } \\
\text { living in } \\
\text { Pavlodar as a } \\
\text { method of an } \\
\text { environmental } \\
\text { assessment of } \\
\text { the quality of } \\
\text { urban ecosystem } \\
\text { under conditions } \\
\text { of long } \\
\text { technogenic } \\
\text { impact }\end{array}$ & $\begin{array}{l}\text { Children hair } \\
12-14 \text { y.o. } \\
(\mathrm{n}=100)\end{array}$ & $\begin{array}{l}\text { Instrumental } \\
\text { neutron } \\
\text { activation } \\
\text { analysis } \\
\text { (INAA) }\end{array}$ & $\begin{array}{l}\text { Highest } \mathrm{Hg} \text { accumulation in } \mathrm{W}, \mathrm{SW} \\
\mathrm{NW} \text { districts }=0.5-0.7 \mathrm{mg} / \mathrm{kg} \text { due to } \\
\text { proximity to the industrial zone } \\
\text { Uneven distribution of toxic elements } \\
\text { in human biosubstrates }\end{array}$ & $\begin{array}{l}\text { High } \mathrm{Hg} \text { and } \mathrm{Zn} \text { content } \\
\text { due to high mobility in } \\
\text { "soil-snow- } \\
\text { plants-biosubstrates } \\
\text { (hair)" system } \\
\text { Two groups of main } \\
\text { exposure sources: coal } \\
\text { energy and metal } \\
\text { industry (Hg, } \mathrm{Zn} \text { ); } \\
\text { chemical }(\mathrm{Hg}, \mathrm{Se}, \mathrm{Rb}) \\
\text { and petrochemicals ( } \mathrm{Zn} \text {, } \\
\text { Se); } \\
\text { Most contaminated } \\
\text { districts: NW, W, SW }\end{array}$ & \\
\hline
\end{tabular}


Table 2. Cont.

\begin{tabular}{|c|c|c|c|c|c|c|c|}
\hline Study & Title & Objective & Sampling & Analysis & Main Findings & Conclusions & Recommendations \\
\hline $\begin{array}{l}2011 \\
\text { Ilyuchshenko } \\
\text { et al. [63] }\end{array}$ & $\begin{array}{l}\text { Final technical } \\
\text { report }\end{array}$ & $\begin{array}{l}\text { (1) Risk } \\
\text { assessment on } \\
\text { the flow } \\
\text { direction of } \\
\text { groundwater } \\
\text { polluted with oil } \\
\text { products and Hg, } \\
\text { including its } \\
\text { passage through } \\
\text { sampling wells } \\
\text { in } \\
\text { Pavlodarskoye } \\
\text { village, joining } \\
\text { River Irtysh } \\
\text { and/or } \\
\text { resurfacing at } \\
\text { pastures. In case } \\
\text { of high risk, } \\
\text { building strategy } \\
\text { to control and } \\
\text { minimize it; } \\
\text { (2) Building risk } \\
\text { management } \\
\text { strategy for the } \\
\text { environment } \\
\text { from Hg } \\
\text { pollution of Lake } \\
\text { Balkyldak, } \\
\text { including } \\
\text { pollutants } \\
\text { bioaccumulation } \\
\text { in the food chain. }\end{array}$ & $\begin{array}{l}\text { Surface and } \\
\text { ground water } \\
(\mathrm{n}=800), \\
\text { bottom } \\
\text { sediment } \\
(\mathrm{n}=334) \text {, soil } \\
(\mathrm{n}=610) \text {, grass } \\
(4 \mathrm{~g}), \text { biota } \\
\text { from } \\
\text { Balkyldak } \\
(\mathrm{n}=132) ; \\
\text { water for } \\
\text { MeHg ( } \mathrm{n}=3) \text {, } \\
\text { Hydrogeologic } \\
\text { modeling for } \\
\text { risk } \\
\text { assessment } \\
\text { and } \\
\text { management } \\
\text { of } \\
\text { groundwater } \\
\text { pollution via } \\
\text { ModFlow } \\
\text { GMS 5.0. } \\
\text { Sampling plan } \\
\text { of top } 3 \text { soil } \\
\text { layers (0-10, } \\
\text { 10-20, 20-50 } \\
\text { cm) in a } \\
\text { regular grid } \\
\text { with a varying } \\
\text { sampling step }\end{array}$ & $\begin{array}{l}\text { AAS (Lumex } \\
\text { RA 915+); } \\
\text { AFS (PS } \\
\text { Analytical } \\
\text { Millennium } \\
\text { Merlin } \\
\text { System) }\end{array}$ & $\begin{array}{l}\text { Computer model of Hg contamination } \\
\text { of groundwater verified by Hg analysis } \\
\text {-> predicted Hg transport within } 30 \mathrm{y} \\
\text { Hg plume in groundwater continues to } \\
\text { spread in N-NW direction of the plant } \\
\text {-> high risk of pollution of topsoil } \\
\text { layers } \\
\text { Hg levels in GW in the eastern } \\
\text { direction are falling as predicted by } \\
\text { computer modeling } \\
\text { Hg levels on plant's territory are } \\
\text { unpredictable, but in topsoils of most } \\
\text { parts are very high despite } \\
\text { demercuration efforts } \\
\text { Waste storage facilities of PCP show } \\
\text { good isolation results } \\
\text { The estimated amount of Hg discarded } \\
\text { in Lake Balkyldak by the } \\
\text { plant- } 135,336 \mathrm{~kg} \\
\text { Hg levels of surface waters of } \\
\text { Balkyldak decreased after the burial of } \\
\text { Hg waste } \\
\text { Hg levels of biota fell as well, but some } \\
\text { fish specimen had high Hg levels in } \\
2007 \text { (1-1.5 mg/kg) }\end{array}$ & $\begin{array}{l}\text { Topsoils and vegetation: } \\
>2.1 \mathrm{mg} / \mathrm{kg} \text { (MPC) in } \\
\text { selected sites with } \\
\text { Hg-bearing } \\
\text { groundwater; in soils on } \\
\text { PCP site extremely } \\
\text { high-up to x1000 MPC } \\
\text { Groundwater: } \\
\text { extremely irregular } \\
\text { decrease; high risk of } \\
\text { formation of new } \\
\text { hotspots of soil } \\
\text { contamination on PCP } \\
\text { territory due to the } \\
\text { transport of soluble Hg } \\
\text { to aeration zone; no risk } \\
\text { of the Irtysh and } \\
\text { water-supply wells of } \\
\text { Pavlodarskoye village } \\
\text { contamination if } \\
\text { hydro-geological } \\
\text { conditions remain same; }\end{array}$ & $\begin{array}{l}\text { (1) Create a } \\
\text { monitoring } \\
\text { laboratory for PCP } \\
\text { to complete } \\
\text { implementation of } \\
\text { post-demercuration } \\
\text { monitoring } \\
\text { programs } \\
\text { (2) Treatment for } \\
\text { soils: pulpation + } \\
\text { gravitational } \\
\text { separation } \\
\text { (3) Bioremediation } \\
\text { of groundwater to } \\
\text { immobilize Hg } \\
\text { (4) Sediments: pump } \\
\text { using a dredger and } \\
\text { move to an isolated } \\
\text { pond with } \\
\text { subsequent } \\
\text { evaporation and } \\
\text { burial } \\
\text { (5) Ban the } \\
\text { consumption of fish } \\
\text { from Balkyldak } \\
\text { (6) 2nd phase of } \\
\text { demercuration plan } \\
\text { to address: } \\
\text { (i) treatment and } \\
\text { remediation of soils } \\
\text { on plant's territory } \\
\text { (ii) Hg } \\
\text { immobilization in } \\
\text { groundwater } \\
\text { (iii) treatment of } \\
\text { Balkyldak's } \\
\text { sediments }\end{array}$ \\
\hline
\end{tabular}


Table 2. Cont

\begin{tabular}{|c|c|c|c|c|c|c|c|}
\hline Study & Title & Objective & Sampling & Analysis & Main Findings & Conclusions & Recommendations \\
\hline $\begin{array}{l}2016 \text { Shakhova } \\
\text { et al. [64] }\end{array}$ & $\begin{array}{l}\text { Evaluation of } \\
\text { mercury } \\
\text { contamination in } \\
\text { the vicinity of } \\
\text { enterprises of the } \\
\text { petrochemical } \\
\text { complex in the } \\
\text { winter period } \\
\text { (based on the } \\
\text { example of } \\
\text { Pavlodar, } \\
\text { Republic of } \\
\text { Kazakhstan) }\end{array}$ & $\begin{array}{l}\text { To evaluate } \\
\text { mercury } \\
\text { pollution in the } \\
\text { vicinity of } \\
\text { petrochemical } \\
\text { complex } \\
\text { enterprises } \\
\text { during the } \\
\text { winter period } \\
\text { (on the example } \\
\text { of Pavlodar) } \\
\text { according to the } \\
\text { study } \\
\text { of/investigating/ } \\
\text { analyzing the } \\
\text { snow cover as } \\
\text { storage of solid } \\
\text { particles. }\end{array}$ & $\begin{array}{l}\text { Snow from } 11 \\
\text { locations }(1 \\
\text { sample of } \\
10-12 \mathrm{~L}), \\
\text { number of } \\
\text { samples at the } \\
\text { closest } \\
\text { residential } \\
\text { area }=5\end{array}$ & $\begin{array}{l}\text { AAS (Lumex } \\
\text { RA 915+ and } \\
\text { PYRO 915) }\end{array}$ & $\begin{array}{l}\text { (1) } \mathrm{Hg} \text { concentration in solid fraction of } \\
\text { snow exceeds max allowable } \\
\text { concentration by } 1.5-7 \text { times. In NE } \\
\text { zone: } 0.31-1.04 \mathrm{mg} / \mathrm{kg} \text {, SW: } 0.22 \mathrm{mg} / \mathrm{kg} \text {, } \\
\text { NW: } 0.03-0.26 \mathrm{mg} / \mathrm{kg} \text {, background } \\
0.15 \mathrm{mg} / \mathrm{kg} \text {; in Pavlodarskoe village } \\
\text { close to background } \\
\text { Daily mean Hg deposited on snow } \\
\text { cover } 4.9-221 \mathrm{mg} /\left(\mathrm{km}^{2} \times \text { day); }\right. \\
\text { max }-1.5 \mathrm{~km} \text { from the plant, NE zone }\end{array}$ & $\begin{array}{l}\text { High } \mathrm{Hg} \text { concentrations } \\
\text { in the NE zone might be } \\
\text { related to technogenic } \\
\mathrm{Hg} \text { contamination and } \\
\text { wind directions; } \mathrm{Hg} \\
\text { depositions and } \\
\text { concentrations in snow } \\
\text { covers are high } \\
(0.03-1.04 \mathrm{mg} / \mathrm{kg}) \text { in the } \\
\text { vicinity }(0.5-2.5 \mathrm{~km}) \\
\text { from PCP }\end{array}$ & $\begin{array}{l}\text { The data obtained } \\
\text { can be used for } \\
\text { planning of } \\
\text { environmental } \\
\text { activities, such as air } \\
\text { monitoring in the } \\
\text { northern industrial } \\
\text { zone of Pavlodar, as } \\
\text { well as for further } \\
\text { monitoring of health } \\
\text { risks of the Pavlodar } \\
\text { region population }\end{array}$ \\
\hline
\end{tabular}


Table 3. Comparison of two cases of $\mathrm{Hg}$ contamination in Kazakhstan.

\begin{tabular}{|c|c|c|}
\hline Case & Pavlodar (Includes Balkyldak Lake and Irtysh River) & Nura River \\
\hline Source of contamination & $\begin{array}{l}\text { Chlorine and caustic soda production at the JSC "Pavlodar Chemical } \\
\text { Plant," Hg used in electrolysis }\end{array}$ & $\begin{array}{l}\text { Acetaldehyde production at the Temirtau chemical plant by } \\
\text { direct } \mathrm{C}_{2} \mathrm{H}_{2} \text { hydration in the presence of } \mathrm{HgSO}_{4}\end{array}$ \\
\hline Years of operation & 1975-1993 & $1950-1997$ \\
\hline Contaminated zones & $\begin{array}{l}\text { The territory of the plant, lake Balkyldak for wastewater discharge, } \\
\text { Shoptykol }\end{array}$ & $\begin{array}{l}\text { Nura river (mainly close to the discharge point), Intumak and } \\
\text { Samarkand reservoirs, Swamp Zhaur, old ash lagoon of } \\
\text { KarGRES-1 and wastewater treatment facilities, terminal } \\
\text { wetlands of Korgalzhyn National Park }\end{array}$ \\
\hline $\mathrm{Hg}$ quantities discharged & $\begin{array}{l}1300 \mathrm{t}[65] ; 1000 \mathrm{t}[50] ; 19 \mathrm{t} \text { on the territory of the site [59]; discarded } \\
\text { into lake 135 } \mathrm{t}[63]\end{array}$ & 2351.6 tons of $\mathrm{Hg}$ consumed [19] \\
\hline $\begin{array}{l}\text { Hg concentrations in soil and } \\
\text { groundwater }(\mathrm{mg} / \mathrm{kg} \text { for soils, } \\
\mathrm{mg} / \mathrm{L} \text { for water })\end{array}$ & 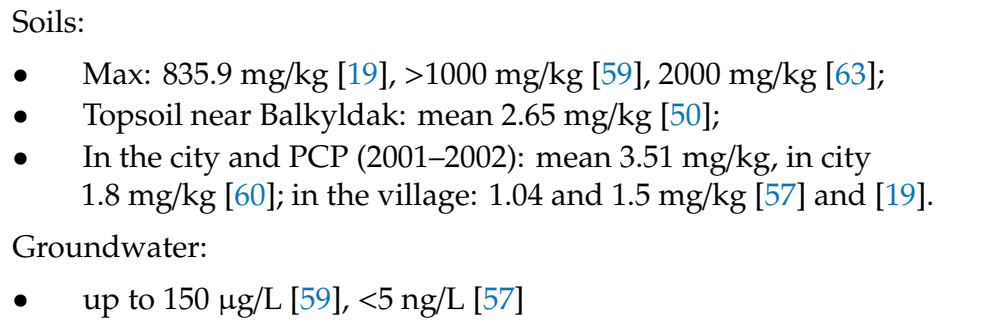 & $\begin{array}{l}\text { Soil: } \\
\text { - } \quad \text { Local hotspot (Swamp Zhaur): mean } 306.7 \mathrm{mg} / \mathrm{kg} \text { [66]; } \\
\text { - In Nura floodplain and banks between Samarkand and } \\
\text { Intumak reservoirs: } 0.01-100 \mathrm{mg} / \mathrm{kg} \text {, mean } 5.9 \mathrm{mg} / \mathrm{kg} \\
12.5 \mathrm{~km} \text { downstream, } 10 \mathrm{mg} / \mathrm{kg} 60 \mathrm{~km} \text { downstream [55] }\end{array}$ \\
\hline $\begin{array}{l}\text { Hg concentrations in water } \\
\text { (mean) }\end{array}$ & $\begin{array}{l}\text { - } \quad 0.11-1.39 \mu \mathrm{g} / \mathrm{L} \text { with an increase up to } 7.3 \mu \mathrm{g} / \mathrm{L} \text { on windy days [50] } \\
\text { - } \quad \text { undetectable and trace levels [50,59]. }\end{array}$ & $\begin{array}{l}\text { - Surface water in flood periods: } 1.6-4.3 \mu \mathrm{g} / \mathrm{L} \text { [61], } 0.5 \mu \mathrm{g} / \mathrm{L} \\
\text { to } 1.25 \mu \mathrm{g} / \mathrm{L}[54] \\
\text { During other seasons-usually }<0.5-1 \mu \mathrm{g} / \mathrm{L} \text {, sometimes } \\
>0.3 \mu \mathrm{g} / \mathrm{L}[54,66] \\
\text { - } \quad \text { Intumak reservoir and further terminal wetlands in the } \\
\text { Korgalzhyn National Park }<5 \mathrm{ng} / \mathrm{L}[54,61]\end{array}$ \\
\hline $\begin{array}{l}\text { Hg concentrations in sediments } \\
\text { (mean) }\end{array}$ & $\begin{array}{l}\text { - wastewater outfall pipe- } 167 \mathrm{mg} / \mathrm{kg} \text {, old river channel > } \\
0.050 \mathrm{mg} / \mathrm{kg} \text { [50] } \\
\text { - more distant locations-40-60 mg/kg [50] }\end{array}$ & $\begin{array}{l}\text { - The highest concentration }(150-240 \mathrm{mg} / \mathrm{kg}) \text { - within the } \\
\text { first } 15 \mathrm{~km} \mathrm{[54]} \\
\text { - } 9.95-306 \mathrm{mg} / \mathrm{kg} \text { in the most polluted section [61] }\end{array}$ \\
\hline
\end{tabular}


Table 3. Cont.

\begin{tabular}{|c|c|c|}
\hline Case & Pavlodar (Includes Balkyldak Lake and Irtysh River) & Nura River \\
\hline $\begin{array}{l}\text { Hg in air, biota, hair, blood } \\
\text { (mean) }\end{array}$ & 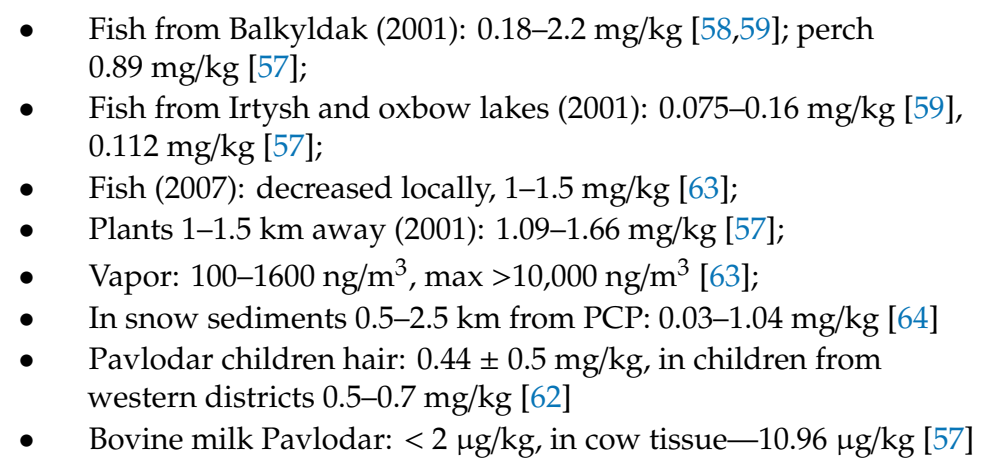 & $\begin{array}{l}\text { - } \quad \text { River fish (2002): } 0.325-0.923 \mu \mathrm{g} / \mathrm{g} \text { [3]; crayfish caught and } \\
\text { bought from local market: } 0.043 \text { and } 0.026 \mathrm{mg} / \mathrm{kg} \mathrm{[61]} \text {; } \\
\text { - } \quad \text { The narrow-leaf cattail from riverbanks }(0.03-0.63 \mathrm{mg} / \mathrm{kg}) \\
\text { - } \quad \text { Temirtau region's citizens' hair-0.009-5.184 } \mu \mathrm{g} / \mathrm{g} \text { [3] }\end{array}$ \\
\hline
\end{tabular}


Table 4. Comparison of selected international cases.

\begin{tabular}{|c|c|c|c|c|c|c|c|c|c|}
\hline & Facility & $\begin{array}{l}\text { Years of } \\
\text { Operation }\end{array}$ & $\begin{array}{l}\text { Production } \\
\text { Capacity }\end{array}$ & $\begin{array}{l}\text { Estimated } \\
\text { Discharge }\end{array}$ & $\begin{array}{l}\mathrm{Hg} \text { in Soils } \\
(\mathrm{mg} / \mathrm{kg})\end{array}$ & $\begin{array}{c}\text { Hg in } \\
\text { Sediments } \\
(\mathrm{mg} / \mathrm{kg})\end{array}$ & $\begin{array}{l}\mathrm{Hg} \text { in Water } \\
(\mathrm{ng} / \mathrm{L})\end{array}$ & Main Remarks & $\begin{array}{l}\text { Reviewed } \\
\text { References }\end{array}$ \\
\hline $\begin{array}{l}\text { Temirtau, } \\
\text { Kazakhstan }\end{array}$ & Acetaldehyde & 1950-1997 & $\begin{array}{l}\text { Not reported } \\
\text { in reviewed } \\
\text { references }\end{array}$ & 1200 t [67] & $\begin{array}{c}0.01 \text { to over } 100 \\
\text { [55] } \\
\text { up to } 1974 \text { [66] }\end{array}$ & $\begin{array}{l}150-240[54] \\
9.95-306[50]\end{array}$ & $\begin{array}{c}500-1250[54] \\
1600-4300[50]\end{array}$ & $\begin{array}{l}\text { Reviewed in detail in the present study } \\
\text { (Refer to Table 3). }\end{array}$ & {$[50,66,67]$} \\
\hline $\begin{array}{l}\text { Schkopau, } \\
\text { Germany }\end{array}$ & Acetaldehyde & $\begin{array}{c}\text { Before } \\
1942-1989\end{array}$ & $\begin{array}{l}142,800-300,000 \\
t / y\end{array}$ & $\begin{array}{l}\text { Not reported } \\
\text { in reviewed } \\
\text { references }\end{array}$ & $\begin{array}{c}14 \text { to over } 1000 \\
{[68]}\end{array}$ & $\begin{array}{l}\text { Not reported } \\
\text { in reviewed } \\
\text { references }\end{array}$ & $\begin{array}{l}\text { Not reported } \\
\text { in reviewed } \\
\text { references }\end{array}$ & $\begin{array}{l}\text { An industrial complex with three } \\
\text { chlor-alkali plants and one acetaldehyde } \\
\text { plant [68]; } \\
\text { A strong source of atmospheric } \mathrm{Hg} \\
\text { emissions }(0.2-1.7 \mathrm{~kg} / \text { day) [69]; } \\
\text { High levels of organic } \mathrm{Hg} \text { compounds in } \\
\text { the plant's soils, possibly due to reaction } \\
\text { of } \mathrm{Hg}^{0} \text { with carbide }\left(\mathrm{CaC}_{2}\right) \text { dust covering } \\
\text { the site's soils, reaction of } \mathrm{Hg} \text { with soil's } \\
\text { humus, intermediate reactions in } \\
\text { acetaldehyde production [68]. }\end{array}$ & [68-70] \\
\hline $\begin{array}{l}\text { Minamata, } \\
\text { Japan }\end{array}$ & Acetaldehyde & 1932-1968 & $\begin{array}{l}\text { Not reported } \\
\text { in reviewed } \\
\text { references }\end{array}$ & 250 t [71] & $\begin{array}{l}\text { Not reported in } \\
\text { reviewed } \\
\text { references }\end{array}$ & $\begin{array}{c}\text { Before } \\
\text { dredging: up } \\
\text { to 2000 [71] } \\
\text { After } \\
\text { dredging: } \\
0.49-3.4 \text { [72] } \\
0.61-6.73 \text { [71] }\end{array}$ & $\begin{array}{c}1.3-4.3 \text { (total } \\
{[71] \text { ) }} \\
0.10-0.95 \\
\text { (dissolved } \\
\text { [73]) }\end{array}$ & $\begin{array}{c}>2200 \text { registered cases of Minamata } \\
\text { disease in the area by } 2003 \text { [72]; } \\
\text { Dredging in 1974-1990 to decrease } \\
\text { sediment Hg below } 25 \mathrm{mg} / \mathrm{kg}[72] ; \\
\mathrm{Hg} \text { in sediments still } 70 \text { times higher than } \\
\text { background levels [71]; } \\
254 \% \text { of total Hg in the bottom water layer } \\
\text { is MeHg }>>\text { MeHg is the main form of Hg } \\
\text { from sediment to water [71]. }\end{array}$ & [71-73] \\
\hline $\begin{array}{l}\text { Qingzhen, } \\
\text { Guizhou, } \\
\text { China }\end{array}$ & $\begin{array}{l}\text { Acetic acid } \\
\text { and } \\
\text { acetaldehyde }\end{array}$ & 1971-2000 & $\begin{array}{l}\text { Not reported } \\
\text { in reviewed } \\
\text { references }\end{array}$ & 134.6 t [74] & $\begin{array}{c}14.3+-0.1 \text { to } \\
354+-15[75] \\
0.06-321.38[74] \\
0.14-259.56[76]\end{array}$ & $\begin{array}{l}\text { Not reported } \\
\text { in reviewed } \\
\text { references }\end{array}$ & $\begin{array}{c}450-1830 \\
\text { (total) } \\
12.7-16.1 \\
\text { (dissolved [75] }\end{array}$ & $\begin{array}{c}\text { Site conditions similar to Nura River; } \\
\text { Total daily intake in } \mu \mathrm{g} / \mathrm{kg} \text { of } 60 \mathrm{~kg} \text { body } \\
\text { weight for rice (inorganic } \\
\mathrm{Hg}-0.001-0.003, \mathrm{MeHg}-0.005-0.019) \\
\text { irrigated by polluted river water and fish } \\
\text { (inorganic } \mathrm{Hg}-0.000-0.003 \text {, } \\
\mathrm{MeHg}-0.01-0.13 \text { ) were estimated and } \\
\text { exceeded values recommended by U.S. } \\
\text { EPA [75]. }\end{array}$ & [74-76] \\
\hline
\end{tabular}


Table 4. Cont.

\begin{tabular}{|c|c|c|c|c|c|c|c|c|c|}
\hline & Facility & $\begin{array}{l}\text { Years of } \\
\text { Operation }\end{array}$ & $\begin{array}{l}\text { Production } \\
\text { Capacity }\end{array}$ & $\begin{array}{l}\text { Estimated } \\
\text { Discharge }\end{array}$ & $\underset{(\mathrm{mg} / \mathrm{kg})}{\mathrm{Hg} \text { in Soils }}$ & $\begin{array}{c}\mathrm{Hg} \text { in } \\
\text { Sediments } \\
(\mathrm{mg} / \mathrm{kg})\end{array}$ & $\begin{array}{l}\mathrm{Hg} \text { in Water } \\
\text { (ng/L) }\end{array}$ & Main Remarks & $\begin{array}{l}\text { Reviewed } \\
\text { References }\end{array}$ \\
\hline $\begin{array}{l}\text { Pavlodar, } \\
\text { Kazakhstan }\end{array}$ & $\begin{array}{l}\text { Hg-cell } \\
\text { chlor-alkali } \\
\text { plant }\end{array}$ & 1975-1993 & $\begin{array}{c}100,000 \mathrm{t} \text { of } \\
\mathrm{Cl}_{2} / \mathrm{y}\end{array}$ & $\begin{array}{c}1000-1300 \mathrm{t} \\
{[50,65]}\end{array}$ & $\begin{array}{c}\text { 0.0067-835.9 } \\
{[19]} \\
0.22-5.72 \\
\text { (around the lake, } \\
\text { excluding the } \\
\text { plant's site, [50]) } \\
\text { up to } 2000 \text { [63] }\end{array}$ & $0.11-617[50]$ & $110-7300[50]$ & $\begin{array}{l}\text { Reviewed in detail in the present study } \\
\text { (Refer to Table 3). }\end{array}$ & {$[19,50,63,65]$} \\
\hline $\begin{array}{c}\text { Penobscot } \\
\text { River, Maine, } \\
\text { US }\end{array}$ & $\begin{array}{l}\text { Hg-cell } \\
\text { chlor-alkali } \\
\text { plant }\end{array}$ & 1967-2012 & $\begin{array}{l}65,700 \mathrm{t} \text { of } \\
\mathrm{Cl}_{2} / \mathrm{y}\end{array}$ & $9 t$ & $\begin{array}{l}\text { Not reported in } \\
\text { reviewed } \\
\text { references }\end{array}$ & $0.35-1.10$ [77] & $\begin{array}{l}2 \text { (dissolved } \\
[77])\end{array}$ & $\begin{array}{l}\text { Slow drainage of } \mathrm{Hg} \text { from the site into the } \\
\text { river (5.4 g/day) with increased loading } \\
\text { during major storm events [78]; } \\
\text { site groundwater input of Hg amounted } \\
\text { to } 17 \mathrm{~g} / \mathrm{day} \text { in the } 1990 \mathrm{~s} \text { and decreased to } \\
0.11 \mathrm{~g} / \text { day in } 2009 \text { due to capture and } \\
\text { treatment of site groundwater [78]; slow } \\
\text { recovery of river's aquatic food web, need } \\
\text { for longer monitoring [79]. }\end{array}$ & [77-79] \\
\hline Flix, Spain & $\begin{array}{l}\text { Hg-cell } \\
\text { chlor-alkali } \\
\text { plant }\end{array}$ & 1949-2017 & $\begin{array}{l}115,200 t \text { of } \\
\mathrm{Cl}_{2} / \mathrm{y}\end{array}$ & $\begin{array}{l}\text { Not reported } \\
\text { in reviewed } \\
\text { references }\end{array}$ & $\begin{array}{c}0.044-12.9[80] \\
1.7-61.6[81]\end{array}$ & $\begin{array}{l}0.098-495[80] \\
\text { up to } 640[82]\end{array}$ & $\begin{array}{l}\text { Not reported } \\
\text { in reviewed } \\
\text { references }\end{array}$ & $\begin{array}{l}\text { The current pollution source is a sludge } \\
\text { deposit formed at the riverbank close to } \\
\text { the dam and containing approximately } \\
10-18 \mathrm{Mg} \text { of } \mathrm{Hg} \text { [ } 83] \text {; } \\
\text { Several dams placed upstream and } \\
\text { downstream of the plant resulted in } \\
\text { accumulation of waste containing } \mathrm{Hg} \text { at } \\
\text { the base of the downstream dam in the } \\
\text { absence of natural dilution and burial } \\
\text { with river sediment material [82]; } \\
\text { removal of the contaminated deposit has } \\
\text { started [81,82]. Elevated atmospheric Hg } \\
\text { levels in the region ( } 229 \mathrm{ng} / \mathrm{m}^{3} \text { in the } \\
\text { vicinity of the plant) exceeding guideline } \\
\text { thresholds for a residential area in Flix } \\
\text { town [80]. }\end{array}$ & [80-83] \\
\hline
\end{tabular}


Table 4. Cont.

\begin{tabular}{|c|c|c|c|c|c|c|c|c|c|}
\hline & Facility & $\begin{array}{c}\text { Years of } \\
\text { Operation }\end{array}$ & $\begin{array}{l}\text { Production } \\
\text { Capacity }\end{array}$ & $\begin{array}{l}\text { Estimated } \\
\text { Discharge }\end{array}$ & $\underset{(\mathrm{mg} / \mathrm{kg})}{\mathrm{Hg} \text { in Soils }}$ & $\begin{array}{c}\mathrm{Hg} \text { in } \\
\text { Sediments } \\
(\mathrm{mg} / \mathrm{kg})\end{array}$ & $\begin{array}{c}\mathrm{Hg} \text { in Water } \\
(\mathrm{ng} / \mathrm{L})\end{array}$ & Main Remarks & $\begin{array}{l}\text { Reviewed } \\
\text { References }\end{array}$ \\
\hline $\begin{array}{l}\text { Estarreja, } \\
\text { Portugal }\end{array}$ & $\begin{array}{l}\text { Hg-cell } \\
\text { chlor-alkali } \\
\text { plant }\end{array}$ & 1950-2002 & $\begin{array}{l}\text { Not reported } \\
\text { in reviewed } \\
\text { references }\end{array}$ & over $50 t$ & $\begin{array}{c}0.18-49.23[84] \\
0.01-90.8[85]\end{array}$ & $\begin{array}{c}\text { Up to } 180[84] \\
0-48[86]\end{array}$ & $\begin{array}{c}7-84 \\
\text { (dissolved } \\
\text { [86]) } \\
\text { 12-847 (total } \\
\text { [85]) }\end{array}$ & $\begin{array}{c}\text { About } 8 \mathrm{~km}^{2} \text { area around the plant has } \\
\text { been identified as a heavily contaminated } \\
\text { zone [84]; } \\
\text { Hg tightly binds to topsoils with a size } \\
\text { fraction }<0.063 \text { mm, possibility of } \\
\text { groundwater contamination [84]; } \\
\text { Hg concentrations in surface sediments } \\
\text { were lower than those in deeper parts, } \\
\text { indicating higher historical Hg releases } \\
\text { with pieces of evidence of remobilization of } \\
\text { Hg in water in reducing environments [86]. } \\
\text { Agricultural soils located close to the } \\
\text { plant's past effluent discharge spot contain } \\
\text { high Hg levels and recommended to be } \\
\text { restricted from use and remediated [85]. }\end{array}$ & [84-86] \\
\hline $\begin{array}{l}\text { Dalhousie, } \\
\text { New } \\
\text { Brunswick, } \\
\text { Canada }\end{array}$ & $\begin{array}{l}\text { Hg-cell } \\
\text { chlor-alkali } \\
\text { plant }\end{array}$ & 1963-2008 & $\begin{array}{c}34,300 \mathrm{t} \text { of } \\
\mathrm{Cl}_{2} / \mathrm{y}\end{array}$ & $\begin{array}{c}141-163 \mathrm{t}(2 \\
\text { chlor-alkali } \\
\text { plants of } \\
\text { Canada [87]) }\end{array}$ & $\begin{array}{l}\text { Not reported in } \\
\text { reviewed } \\
\text { references }\end{array}$ & $\begin{array}{l}<0.1-8.1[88] \\
0.02-1.96[88] \\
0.04-0.28[89]\end{array}$ & $\begin{array}{c}\text { 840-4320 } \\
\text { (total, in } \\
\text { effluents [88]) }\end{array}$ & $\begin{array}{l}\text { Atmospheric Hg emissions from the } \\
\text { facility in 1988-1996 were in the range } \\
31-70 \mathrm{~kg} / \mathrm{y} \text {, with } 2.5 \text { times higher Hg } \\
\text { quantities discharged in the facility's } \\
\text { landfilled sludge [90]; } \\
\text { The sludge pile close to the plant contains } \\
\text { approximately } 2.5 \mu \mathrm{g} \text { of } \mathrm{Hg} / \mathrm{g} \text { in the form } \\
\text { of } \mathrm{Hg} \text { sulfides [90]; } \\
\mathrm{Hg} \text { content in sediment samples close to } \\
\text { the plant exceed Canadian guideline } \\
\text { values ( } 0.13 \mathrm{mg} / \mathrm{kg} \text { ) [88]; Recent } \\
\text { observations indicate natural recovery due } \\
\text { to sediment deposition [89]. }\end{array}$ & [87-90] \\
\hline $\begin{array}{l}\text { Rm Valcea, } \\
\text { Romania }\end{array}$ & $\begin{array}{l}\text { Hg-cell } \\
\text { chlor-alkali } \\
\text { plant }\end{array}$ & $\begin{array}{c}\text { 1968-present } \\
\text { [91] }\end{array}$ & $\begin{array}{l}210,000 \mathrm{t} \text { of } \\
\mathrm{Cl}_{2} / \mathrm{y}\end{array}$ & $\begin{array}{c}36-53 \mathrm{t} \\
\text { (estimated } \\
\text { based on data } \\
\text { from [91]) }\end{array}$ & $\begin{array}{l}\text { Not reported in } \\
\text { reviewed } \\
\text { references }\end{array}$ & $0.5-45$ [91] & $\begin{array}{c}\text { 9-88 } \\
\text { (dissolved } \\
\text { [92]) }\end{array}$ & $\begin{array}{l}\text { Fluctuations in } \mathrm{Hg} \text { concentration in } \\
\text { sediment cores - }>\text { flooding cause the } \\
\text { transport of contaminated soil from the site } \\
\text { to the river sediments [91]; } \\
\text { Bravo et al. [91] strongly discouraged any } \\
\text { treatment actions involving rework or } \\
\text { dredging of the sediments due to the risk } \\
\text { of resuspension of buried highly } \\
\text { contaminated particles. }\end{array}$ & {$[91,92]$} \\
\hline
\end{tabular}




\section{Site \#1: Lake Balkyldak and Pavlodar Region}

During the operation of the chlor-alkali plant in Pavlodar, $\mathrm{Hg}$ was used as a cathode in the electrolytic separation of chlorine and caustic soda from brine resulting in large quantities of $\mathrm{Hg}$-rich sludge. A significant part of it has been discharged to the soil and atmosphere in the vicinity of the plant [19]. Some estimates of the Hg losses at PCP were of up to $1300 \mathrm{t}$ [65], although some part of it was allegedly recycled and recovered, the rest (estimated as $700 \mathrm{t}$ ) is still unaccounted [50]. The approximate amount of $\mathrm{Hg}$ discarded to Lake Balkyldak has been estimated at around $135 \mathrm{t}$ [63]. These releases affected different media in the region and significantly influenced the local population making the region an important research subject of numerous studies.

\subsection{Soils}

$\mathrm{Hg}$ concentrations at specific locations were extremely high, sometimes in the order of $\mathrm{g} / \mathrm{kg}$ [63]. Several studies showed that the $\mathrm{Hg}$ concentration in soil exceeded the local permissible limit of $2.1 \mathrm{mg} / \mathrm{kg}$, as well as international limits of $1,6.6$, and $0.83 \mathrm{mg} / \mathrm{kg}$ of the U.S. (California), Canada, and the EU (Netherlands), respectively. Mean soil $\mathrm{Hg}$ concentrations the most contaminated areas were reported to be $835.9 \mathrm{mg} / \mathrm{kg}$ [19], >1000 mg/kg [59], and almost $2000 \mathrm{mg} / \mathrm{kg}$ [63]. Average $\mathrm{Hg}$ in a broader area in the northern industrial zone of the city in 2001-2002 was reported to be $3.51 \mathrm{mg} / \mathrm{kg}$ [60], while mean $\mathrm{Hg}$ was $2.65 \mathrm{mg} / \mathrm{kg}$ in topsoil samples around Lake Balkyldak [50]. The limits for $\mathrm{Hg}$ in soils of industrial areas are higher than that in residential/agricultural soils (Table 1), these reported average concentrations did not exceed the regulations. Two soil sampling campaigns run in Pavlodar and nearby Pavlodarskoye village in 2001-2002 reported mean $\mathrm{Hg}$ lower than $2.1 \mathrm{mg} / \mathrm{kg}$ and $1.8 \mathrm{mg} / \mathrm{kg}$ in the city [60]; and 1.04 and $1.5 \mathrm{mg} / \mathrm{kg}$ in the village [19,57]. Panin and Geldymamedova [60] reported that mean concentrations of several potentially toxic elements (PTEs) (namely $\mathrm{Hg}, \mathrm{Cd}, \mathrm{Co}$, and Mo) were 1.6-22.5 times higher than their background values. However, the sorption of $\mathrm{Hg}$ is not much related to the presence of any other PTEs [13]. Overall, excessively high concentrations have been detected only on the territory of PCP, but not in the inhabited localities.

\subsection{Sediments}

$\mathrm{Hg}$ contamination is present in the sediments of Lake Balkyldak and is more profound in the vicinity of the wastewater outfall pipe (within $1000 \mathrm{~m}$ ) with the mean and peak concentrations of $167 \mathrm{mg} / \mathrm{kg}$ and close to $1500 \mathrm{mg} / \mathrm{kg}$ in 2001-2002, respectively. The Hg content of sediments from the old river channel was less than $0.050 \mathrm{mg} / \mathrm{kg}$ [50]. Occasionally elevated $\mathrm{Hg}$ concentrations $(40-60 \mathrm{mg} / \mathrm{kg}$ ) were detected in the same period in more distant locations of the lake (more than $5 \mathrm{~km}$ from the outfall), possibly linked to sediment transport or disposal of $\mathrm{Hg}$-rich waste at other places. Besides, similar to Nura River sediment-water interaction, resuspension of the sediments (especially from the top layer) might be one of the most critical water contamination sources with $\mathrm{Hg}$ [50]. Finally, highly toxic forms of $\mathrm{Hg}$ (MeHg and other organic $\mathrm{Hg}$ compounds) were found in sediments and fish, possibly linked to bioaccumulation in aquatic food chain [65]. These values may now be deemed outdated, and further studies on Hg's distribution and speciation in the lake's sediments are recommended.

\subsection{Water}

Lake Balkyldak, a wastewater storage pond, has contamination localized, particularly near the discharge pipe in the southern part of the lake. According to Ullrich et al. [50], Hg concentrations in the lake water were $0.11-1.39 \mu \mathrm{g} / \mathrm{L}$ in 2001-2002, increasing to $7.3 \mu \mathrm{g} / \mathrm{L}$ on windy days due to disturbed sediments. After the Hg pollution containment project in 2005-2011 was completed, it was reported that concentrations of $\mathrm{Hg}$ in the surface waters of the lake decreased from a maximum of $3000 \mathrm{ng} / \mathrm{L}$ in 2001 to $300 \mathrm{ng} / \mathrm{L}$ in 2008, since the major part of $\mathrm{Hg}$ waste was sunk [63]. The latter value did not exceed the local regulatory $\mathrm{Hg}$ concentrations, WHO, the U.S. and Canada (Table 1), but was higher than $0.07 \mu \mathrm{g} / \mathrm{L}$, maximum contaminant level in surface water by the EU regulation [39]. 
The analysis of water in the Irtysh River and oxbow lakes in 2001-2005 showed traces or undetectable levels of $\mathrm{Hg}[43,50,59]$. A thorough assessment of the regions' groundwater, including $\mathrm{Hg}$ measurements and modeling, concluded that the movement of the Hg plume is headed to the north in parallel with the river, which implies that the river is not currently receiving polluted groundwater [59,63]. Moreover, groundwater in Pavlodarskoye village is used for local consumption, and its Hg levels did not exceed the level of detection (5 ng/L) in 2001-2002 [57]. In 2005, a plume of contaminated groundwater (up to $150 \mu \mathrm{g} / \mathrm{L}$ ) was revealed to spread in the plant's north-northwestern direction [59]. Six years later, when the containment project was finished, Ilyushchenko et al. [63] reported that the plume continued to spread. Using computer models, the following conclusions were made (assuming the hydro-geological conditions remain unchanged): (i) groundwater contamination in the east direction is expected to decrease, and (ii) $\mathrm{Hg}$ levels in the river water would be in the safe range. Overall, it is expected that the contamination will not significantly affect water in the Irtysh river; however, the Hg levels in lake Balkyldak might be higher. In order to confirm the statement, performing more recent measurements of $\mathrm{Hg}$ levels in groundwater are highly recommended.

\subsection{Biota}

Fish consumption is considered to be the primary source of exposure to $\mathrm{MeHg}$; thus, the region's inhabitants who catch and consume fish from the lake and river could be under certain risks associated with $\mathrm{Hg}$ exposure. While Kazakhstan's limit on maximum permissible $\mathrm{Hg}$ concentration in non-predatory fish is $0.3 \mathrm{mg} / \mathrm{kg}$, the detected levels in fish from the lake were $0.18-2.2 \mathrm{mg} / \mathrm{kg}$, in 50 out of 55 samples exceeding the defined limit $[58,59]$. Comparing $\mathrm{Hg}$ in perch caught from Lake Balkyldak and the Irtysh River, it was obvious that contamination in the lake has been a serious issue: the mean $\mathrm{Hg}$ concentration in samples from Lake Balkyldak was $0.89 \mathrm{mg} / \mathrm{kg}$ (range: $0.16-2.20 \mathrm{mg} / \mathrm{kg}$ ), while the samples from Irtysh River had a mean concentration of $0.112 \mathrm{mg} / \mathrm{kg}$ (range: $0.075-0.125 \mathrm{mg} / \mathrm{kg}$ ) [57]. This finding was in line with the results reported by Ilyushchenko et al. [59]: Hg range in predatory fish from Irtysh River and oxbow lakes was $0.075-0.16 \mathrm{mg} / \mathrm{kg}$. Ilyushchenko et al. [63] reported that $\mathrm{Hg}$ concentrations in the lake biota generally decreased, but Hg levels in some fish in 2007 were $1-1.5 \mathrm{mg} / \mathrm{kg}$, which were at least twice higher than regulatory limits (Table 1). However, it is necessary to note the limited sample size in these studies and the fact that they were conducted before 2007. In terms of flora, several plants in the area 1-1.5 km away from PCP were found to contain $1.09-1.66 \mathrm{mg} / \mathrm{kg}$ of $\mathrm{Hg}$ in the aerial parts. However, $\mathrm{Hg}$ generally tends to accumulate in the root without traveling to the higher parts of the plant [57].

\subsection{Air and Snow}

$\mathrm{Hg}$ can be present in several inter-converting species in different media in the environment, including air, soil, water, sediments, and biota. Since the release took place several decades ago, concentrations of $\mathrm{Hg}$ vapors are expected to be very low unless the $\mathrm{Hg}$ release from contaminated soils, sediments, and water still occur on the site. According to the measurements in 2006, Hg vapor concentrations in the ground-level air were in the range of $100-1600 \mathrm{ng} / \mathrm{m}^{3}$ (MPC of $300 \mathrm{ng} / \mathrm{m}^{3}$ exceeded in 7 out of 16 tested points) [63]. They also detected a $\mathrm{Hg}$ vapor concentration of $>10,000 \mathrm{ng} / \mathrm{m}^{3}$ at one sampling point on the industrial site.

Besides, snow is considered an ideal matrix for observing atmospheric precipitation because it accumulates a great amount of the contaminant due to a larger surface area of snowflakes. Shakhova et al. [64] evaluated the $\mathrm{Hg}$ content in snow and found that the $\mathrm{Hg}$ content in solid snow covers in the vicinity $(0.5-2.5 \mathrm{~km})$ of the chemical plant's site varied greatly and exceeded the background values of $0.15 \mathrm{mg} / \mathrm{kg}$ by 1.5 to 7 times. In NE zone, the reported $\mathrm{Hg}$ content was $0.31-1.04 \mathrm{mg} / \mathrm{kg}$, in SW-0.22 mg/kg, and in NW-0.03-0.26 mg/kg; in Pavlodarskoye village, the value was close to the background. Elevated $\mathrm{Hg}$ concentrations in the $\mathrm{NE}$ zone might be related to $\mathrm{Hg}$ contamination from past industrial activities and wind directions. The results showed that air 
pollution is a real concern in the region; thus, monitoring atmospheric $\mathrm{Hg}$ and its control program are strongly recommended.

\subsection{Hg in Population and Food}

Shaimardanova et al. [62] measured concentrations of $\mathrm{Hg}$ and other PTEs in hair samples collected from the children in Pavlodar. They suggested that high hair $\mathrm{Hg}$ content $(0.44 \pm 0.5 \mathrm{mg} / \mathrm{kg})$ was associated with the activities of high-ash coal thermal power, metal processing plants, and the chemical industry. The most significant $\mathrm{Hg}$ accumulation $(0.5-0.7 \mathrm{mg} / \mathrm{kg})$ was detected in the children's hair living in western, southwestern, and northwestern districts of the city close to the industrial zone. Moreover, some inhabitants of Pavlodarskoye village own livestock, and as a result, drinking Hg-contaminated surface water might pose a risk to cows grazing on the territory around PCP. Hence, there is a significant risk of $\mathrm{Hg}$ exposure via milk and beef consumption. Ullrich et al. [57] assessed the $\mathrm{Hg}$ concentrations in bovine milk and tissue samples and reported the values to be $<2 \mu \mathrm{g} / \mathrm{kg}$ and $10.96 \mu \mathrm{g} / \mathrm{kg}$, respectively. Thus, the $\mathrm{Hg}$ contamination in the industrial zone's vicinity is unlikely to pose health risks to the livestock. However, further studies might be necessary to determine if there is a higher risk for people who consume large quantities of beef liver and kidney as these are the organs with a significant $\mathrm{Hg}$ bioaccumulation [93].

\subsection{Human Health Risk Assessment by Hg Exposure}

Since the significant fraction of $\mathrm{Hg}$ accumulated in fish is present in the organic form, specifically $\mathrm{MeHg}$, consumption of fish from Lake Balkyldak is a crucial issue that was investigated in 2001-2002 [57]. According to the THg values measured in 55 fish samples, 50 of them contained $>0.3 \mathrm{mg} / \mathrm{kg} \mathrm{MeHg}$ (assuming $100 \%$ of $\mathrm{Hg}$ is $\mathrm{MeHg}$ ). The analysis of fish samples caught from Lake Balkyldak in 2006-2007 showed that high Hg levels $(1-1.5 \mathrm{mg} / \mathrm{kg}$ ) were still present in the pond, hence, posing health risks to the local population [63].

Moreover, Woodruff and Dack [19] suggested possible health risks to a local population at village Pavlodarskoye caused by homegrown vegetable consumption due to the potential ingestion of the contaminated soil attached to the vegetables. They used two different risk assessment models from the UK and Netherlands that are mostly based on the intake rate of selected vegetables (with varying rates of accumulation and preparation methods) by the local population. Contaminated Land Exposure Assessment model was used for the case of ingestion of vegetables and soil attached to them. Van Hall Institute Risc-Human Model Version 3.0 for Risk Assessment for Soil Contamination was used for cases of soil ingestion by children, and consumption of meat and vegetables by both children and adults. The estimated risks for children were higher than for adults in all exposure scenarios, possibly due to lower body weight. Another finding was that hazard quotients (HQ) calculated for the scenario of contaminated meat ingestion were higher than the contaminated vegetable intake; however, it is necessary to keep in mind that the dietary patterns vary among people. Besides, the ingestion of contaminated soil poses a high risk due to increased concentrations despite small doses. HQs were in the range of 3.05-3.06 for consuming contaminated vegetables by female children and 6.67 for the ingestion of soil attached to vegetables by female children. Although the authors used these methods, they refrained from clear conclusions due to several limitations that may have affected the risk assessment. For instance, they did not take into consideration $\mathrm{Hg}$ bioaccumulation and difference in vegetable uptake; amounts of ingested soils; and absence of measurements of $\mathrm{Hg}$ levels in hair, blood, and urine.

\section{Site \#2: Nura River and Temirtau Region}

The main river of the Central Kazakhstan region is the Nura River, which has a total length of $978 \mathrm{~km}$ and a catchment area of $60,800 \mathrm{~km}^{2}$ (Figure 1). All rivers of the Nura-Sarysu basin are mainly of snow nutrition; therefore, the bulk of the annual runoff occurs during the flood period in spring. 
The Samarkand reservoir is situated on the Nura River $9 \mathrm{~km}$ downstream from Temirtau and has a total storage capacity of 254 million $\mathrm{m}^{3}$ [22].

The production of acetaldehyde at JSC Carbide was performed using the Kucherov method requiring $\mathrm{Hg}$ (II) sulfate salt as a catalyst, while the contact acid was regenerated with the use of $\mathrm{Hg}$ [20]. Although from the mid-1970s to the mid-1990s, the wastewater discharged from JSC Carbide was treated using various techniques including neutralization, sulfidation, magnetic treatment, the discharges to Nura River ( $2.5 \mathrm{~km}$ from Temirtau) had extremely high $\mathrm{Hg}$ content possibly due to inefficiency of the treatment (Table 2). Moreover, a shallow Intumak reservoir located $75 \mathrm{~km}$ downstream of Temirtau serves as a settling pond for soil particles contaminated with $\mathrm{Hg}$.

\subsection{Soils}

Several studies show that $\mathrm{Hg}$ discharged from the acetaldehyde production plant contaminated different media, including the river floodplain's soils. Thus, Heaven et al. [55] estimated that topsoils of the floodplain along 75-km-long part of the Nura River (from Samarkand reservoir to Intumak reservoir) contained approximately $53 \mathrm{t}$ of $\mathrm{Hg}$, and the concentration range spanned from near background levels $(0.01 \mathrm{mg} / \mathrm{kg})$ to more than $100 \mathrm{mg} / \mathrm{kg}$. Moreover, it was found that the majority of the contaminated materials such as topsoils and technogenic silts (70-90\%) were located in the first $25 \mathrm{~km}$ from Samarkand reservoir [66]. Moreover, the mean concentrations of $\mathrm{Hg}$ in soil were $5.9 \mathrm{mg} / \mathrm{kg}$ (12.5 km downstream) and exceeded the Kazakhstani standard of $2.1 \mathrm{mg} / \mathrm{kg}$ (Table 1) up to ten times and the limits of the U.S. (California) of $1 \mathrm{mg} / \mathrm{kg}$ and of EU (Netherlands) of $0.83 \mathrm{mg} / \mathrm{kg}$ in this region [55]. However, $\mathrm{Hg}$ concentrations in topsoils reduced dramatically with distance from Temirtau, but it still reached the value of $10 \mathrm{mg} / \mathrm{kg}$ at $60 \mathrm{~km}$ downstream. Besides, several local hotspots with high Hg content were reported by Ilyushchenko et al. [66]: Swamp Zhaur (62 t), old ash lagoon of KarGRES-1 (32 t), wastewater treatment facilities, and banks of the main drain from acetaldehyde production plant (10 t). In Zhaur swamp, which was formerly used as a waste disposal area, mean and maximum concentrations of $\mathrm{Hg}$ in soils were $307 \mathrm{mg} / \mathrm{kg}$ and $1974 \mathrm{mg} / \mathrm{kg}$, respectively.

Moreover, $\mathrm{Hg}$ concentrations in soils also tended to be the highest on surface layers and decreased with depth [55]. Although the mobility of $\mathrm{Hg}$ in soils is generally low, it is more mobile in silts and sediments and, as a result, can potentially be mobilized to water. The estimated amount of $\mathrm{Hg}$ accumulated in the bank silt deposits near the riverbanks was $65 \mathrm{t}$ with a mean concentration of $73.3 \mathrm{mg} / \mathrm{kg}$ in the most contaminated section falling to a mean of $13.4 \mathrm{mg} / \mathrm{kg}$ at $70 \mathrm{~km}$ downstream of the river [55].

\subsection{Sediments}

The most polluted sediments were found within 15-20 km downstream of the plant's discharge point with their generally limited transport except during annual flood episodes. Different studies reported the estimated total amounts of technogenic silts formed from the power station fly ash in the riverbed between Samarkand and Intumak reservoirs to be about 463,500-550,000 $\mathrm{m}^{3}$ and contain approximately $10 \mathrm{t}$ of $\mathrm{Hg}[54,66]$. Besides, the total amount of $\mathrm{Hg}$ emissions from the acetaldehyde production plant were estimated to be $1200 \mathrm{t}$ [67]. A wastewater pipe from the plant discharged wastewater directly to the Nura River and is considered one of the most contaminated parts close to the city. The measured $\mathrm{Hg}$ concentrations in the range of $150-240 \mathrm{mg} / \mathrm{kg}$ in sediments are the highest within the first $15 \mathrm{~km}$ [54], and it was $9.95-306 \mathrm{mg} / \mathrm{kg}$ in the most polluted section according to another study conducted in 2001-2002 [61]. Agreeing to the Hg concentrations in soils, technogenic silts, and river sediments, the first 10 to $20 \mathrm{~km}$ from the wastewater discharge point were confirmed to be the most contaminated part of the river [54,56,61,66]. Ullrich et al. [61] reported that the highest $\mathrm{MeHg}$ concentrations in the surface sediments were ranging from 4.9 to $39 \mu \mathrm{g} / \mathrm{kg}$, but usually less than $0.1 \%$ of total $\mathrm{Hg}(\mathrm{THg})$. A significant negative correlation was found between total $\mathrm{Hg}$ concentrations and the $\mathrm{MeHg}$ fraction in the sediments. 
Regarding the suspended particulate matter, Ullrich et al. [61] reported that $\mathrm{Hg}$ in surface waters was mainly adsorbed to particulates. Many international studies reported a significant positive relationship between total $\mathrm{Hg}$ and total suspended solids downstream of contaminated sites [48]. However, it was in strong contrast to an earlier study on the Nura River, where the majority of $\mathrm{Hg}$ downstream of the outfall was found to be in the dissolved form [54].

Overall, $\mathrm{Hg}$ quantities in all media tend to fall with distance along the river, because a significant part of polluted sediments is not moved far downstream except during springtime floods [54,55,61].

\subsection{Water}

Riverbanks erosion and floods may disturb contaminated material such as sediments, silts, and soils, which might result in remobilization and release of $\mathrm{Hg}$ to water [61]. As an example, an increased flow during the flood in 1997 resulted in relative growth of $\mathrm{THg}$ by $235 \%$ (Hg concentrations increased from approximately $0.5 \mu \mathrm{g} / \mathrm{L}$ to $1.25 \mu \mathrm{g} / \mathrm{L}$ ) in the river water near the city of Temirtau [54]. Moreover, during the flood in 2004, $\mathrm{Hg}$ concentrations in surface waters amounted to 1.6-4.3 $\mu \mathrm{g} / \mathrm{L}$ [61]. In contrast, during other seasons, $\mathrm{Hg}$ concentrations in the river usually did not exceed $0.5-1 \mu \mathrm{g} / \mathrm{L}$ but in several cases were higher than $0.3 \mu \mathrm{g} / \mathrm{L}[54,66]$. According to Table 1, Kazakhstani regulations for $\mathrm{Hg}$ concentrations in fish-inhabited waters are more stringent than other international limits, so the values might not comply with several regulations. It is also necessary to consider different limits of detection of the used equipment, sampling locations, time of the year, and other important factors.

According to Heaven et al. [54], the estimated total amount of silt deposited in backwaters was approximately $161,500 \mathrm{~m}^{3}$, and the estimated $\mathrm{Hg}$ quantity was $3.5 \mathrm{t}$. It was suggested that the prevailing part of the silt and $\mathrm{Hg}$ in backwaters were located in the first $25 \mathrm{~km}$ section of the river and that $\mathrm{Hg}$ content in backwaters was directly related to $\mathrm{Hg}$ in riverbed silts.

Talking about $\mathrm{Hg}$ in the Intumak reservoir $75 \mathrm{~km}$ downstream of the river and other terminal wetlands in the Korgalzhyn National Park, the results of different studies showed that the concentrations were higher than the background $(<5 \mathrm{ng} / \mathrm{L})[54,61]$. However, it is recommended to collect and analyze more recent samples, since more than ten years have passed since the last analyses.

\subsection{Biota}

Consumption of local home-produced food might result in human bioaccumulation of $\mathrm{Hg}$, and more importantly, consumption of contaminated fish and shellfish is considered the main $\mathrm{MeHg}$ exposure pathway, since cooking does not remove $\mathrm{Hg}$ from fish. Some people living in Temirtau and surrounding villages consume home-grown vegetables, beef, milk from cows and other livestock, and fish caught from the river [3]. Several studies confirm the bioaccumulation of $\mathrm{Hg}$ in the aqueous food chain. Thus, Ullrich et al. [61] showed that Hg concentration in biota in the most polluted section of the river was 15-20 times higher than the background level, and THg contents in water or sediments cannot be used for prediction of $\mathrm{Hg}$ in fish tissue. Ilyushchenko et al. [66] reported that $\mathrm{Hg}$ in fish and aquatic plants did not exceed the locally defined limits of 0.6 and $0.3 \mathrm{mg} / \mathrm{kg}$ for predatory and non-predatory fish (also complied with international limits from Table 1). The more recent study of fish samples caught locally or purchased from Temirtau markets showed that more than $33 \%$ of the samples contained $\mathrm{Hg}>0.5 \mu \mathrm{g} / \mathrm{g}$. Approximately $84 \%$ of the samples had $\mathrm{Hg}>0.3 \mu \mathrm{g} / \mathrm{g}$, which indicates the possibility of bioaccumulation of $\mathrm{Hg}$ in the aquatic food chain [3]. On the contrary, the results from a study conducted in 2005 reported that crayfish bought on the local market in Temirtau contained $0.026 \mathrm{mg} / \mathrm{kg}$ of $\mathrm{Hg}$, while crayfish caught from the reservoir contained about $0.043 \mathrm{mg} / \mathrm{kg}$ [61]. According to the same study, $\mathrm{Hg}$ was found in fish samples more than $125 \mathrm{~km}$ downstream, indicating a significant transport of dissolved $\mathrm{MeHg}$ to further regions and/or MeHg entering the biological chain in situ in those downstream areas.

Talking about aquatic plants, Hg concentrations in narrow-leaf cattail (Typha angustifolia) from Nura Riverbanks were in the range of $0.03-0.63 \mathrm{mg} / \mathrm{kg}$ with the maximum being near the effluent outfall canal [61]. Although $\mathrm{Hg}$ concentrations in technogenic silts were found to be higher than in the 
epiphytes from the same locations, epiphyte suspension still can be used as an indicator to show the extent of pollution in the watercourse [56].

\subsection{Hg in Population}

Hsiao et al. [3] studied the relationship between human exposure to $\mathrm{Hg}$ and its concentration in the Temirtau region's citizens' and nearby villagers' hair samples. Hg in their hair ranged from 0.009 to $5.184 \mu \mathrm{g} / \mathrm{g}$ with an average value of $0.577 \mu \mathrm{g} / \mathrm{g}$, which was twice as much as in the control group from the Almaty region (considered as non-polluted by $\mathrm{Hg}$ ). Nearly $17 \%$ of the tested population exceeded $1 \mu \mathrm{g} / \mathrm{g}$ for hair $\mathrm{Hg}$, which corresponds to the reference dose (RfD) of $0.1 \mu \mathrm{g} / \mathrm{kg}$ body weight/day developed by the U.S. EPA [34]. A positive correlation was found between $\mathrm{Hg}$ concentration in hair and the consumption frequency of locally caught fish as well as the age: $\mathrm{Hg}$ content in hair of people over 45 years old was higher on average.

\subsection{Comparison Between Cases of Pavlodar and Nura}

In the $\mathrm{Hg}$ contamination cases of Lake Balkyldak and Nura River (Table 3), the main difference is that in the former, the lake was used as an independent wastewater lagoon and received approximately $135 \mathrm{t}$ of $\mathrm{Hg}$ [63], whereas Nura River received treated water as well as accidental $\mathrm{Hg}$ releases in a total amount of around $1200 \mathrm{t}[20,67]$. The literature review showed that $\mathrm{Hg}$ concentrations in soils of the Pavlodar site's most contaminated areas (see Section 3.1) were 3-6 times smaller than $\mathrm{Hg}$ concentrations at the local hotspots at Swamp Zhaur located near Nura River (see Section 4.1). On the other hand, the $\mathrm{Hg}$ concentrations in water remained below the limits in both cases (see Sections 3.3 and 4.3) with the sudden increase in Hg concentration during annual floods and windy days, probably, due to a resuspension of the contaminated sediments [50,61]. It was also found that the $\mathrm{Hg}$ concentrations in sediments are the highest at wastewater outfall pipes (see Sections 3.2 and 4.2) and sediment $\mathrm{Hg}$ levels of the most polluted parts are approximately equal $-160 \mathrm{mg} / \mathrm{kg}$ in the lake and $150-240 \mathrm{mg} / \mathrm{kg}$ in the river $[50,55]$. The reason is related to the increase in specific surface area of the sediment particles thus $\mathrm{Hg}$ is accumulated more in the specific geologic substrate [7]. Measurements of $\mathrm{Hg}$ concentration in plants, fish, and the local population's hair showed that Hg levels of those in the region of Lake Balkyldak are at least two times higher than those in the Nura River region (see Sections 3.6 and 4.4). Overall, the $\mathrm{Hg}$ contamination of the Nura River might affect a larger area because of contaminant transport, but for the same reason, the river is expected to recover faster naturally compared to Lake Balkyldak which is a closed reservoir.

\section{Comparison with Cases from Literature}

Table 4 presents some of the most studied $\mathrm{Hg}$ contamination cases globally due to either acetaldehyde or chlor-alkali production plants, including Kazakhstan cases. Industrial facilities in all of the presented cases either have reduced their $\mathrm{Hg}$ emissions significantly, switched to Hg-free production technologies, or have been decommissioned due to the impact of $\mathrm{Hg}$ released to the local environment for often decades. Both $\mathrm{Hg}$ contamination cases in the Nura River and Lake Balkyldak seem to be more severe than the reported global cases listed in Table 4 . The reviewed cases not only have higher estimated $\mathrm{Hg}$ discharges to the environment (1200 and $1000 \mathrm{t}$, respectively) but also exhibit generally higher Hg levels in soils, sediments, and surface waters in the vicinity of the facilities.

Several studies have investigated the extent of $\mathrm{Hg}$ contamination originating from chlor-alkali plants utilizing Hg-cell technology and its impact on the surrounding environment's soils, sediments, and water. Operation of the chlor-alkali plant located in Flix, Spain, with a production capacity similar to the one in Pavlodar (around 100,000 $\mathrm{t}$ of $\mathrm{Cl}_{2} / \mathrm{y}$ ) caused one of the major episodes of $\mathrm{Hg}$ pollution of the river bed materials. A delta-shaped sludge deposit containing approximately 10-18 Mg of $\mathrm{Hg}$ [83] had been accumulating for several decades at the base of one of several dams along the river in the absence of natural dilution and burial with river sediment material [81,82]. As a result, $\mathrm{Hg}$ concentrations as high as $640 \mathrm{mg} / \mathrm{kg}$ were measured in the accumulated deposits [82]. These are 
close to the range $(0.11-617 \mathrm{mg} / \mathrm{kg})$ reported by Ullrich et al. [50] for Lake Balkyldak sediments. Fluctuations of $\mathrm{Hg}$ concentrations of river sediment cores sampled in the vicinity of a chlor-alkali plant in Rm Valcea, Romania indicate Hg level spikes during floods, which can lead to transport of the site's contaminated soils to the river [91], which might also be the case during annual flooding in Kazakhstan. Local authorities of Flix, Spain, opted for dredging of the polluted deposits [81,82]. However, Bravo et al. [91] strongly discouraged any treatment actions in Rm Valcea involving rework or dredging of the sediments to avoid resuspension of highly contaminated particles, which are buried (around $90 \mathrm{~cm}$ and deeper) in contrast to the ones in Flix.

Another $\mathrm{Hg}$ pollution episode occurred in Estarreja, Portugal, with $8 \mathrm{~km} 2$ around a chlor-alkali plant marked as an extremely contaminated zone $(>1.5 \mathrm{mg} / \mathrm{kg}$ of soil) with most of the soil $\mathrm{Hg}$ bound to silts and clays $(0.063 \mathrm{~mm})$, but as in the case of Pavlodar, the risk of $\mathrm{Hg}$ leaching to groundwater is still present [84]. Several studies on $\mathrm{Hg}$ contamination from chlor-alkali plants comparing their results to other similar works highlighted relatively elevated $\mathrm{Hg}$ levels in water [85] and soils $[85,94]$ of the Lake Balkyldak region. However, the $\mathrm{Hg}$ content of the lake's sediments was one of the highest globally $[82,85,89,91,94]$.

Amidst all global cases of $\mathrm{Hg}$ contamination originating from acetaldehyde plant operations, $\mathrm{Hg}$ pollution of Minamata Bay is arguably the most impactful: population of areas surrounding Minamata bay was exposed to $\mathrm{Hg}$ mainly through the consumption of fish, leading to over 2200 registered cases of Minamata disease (Hg poisoning) in the area by 2003 [72]. The dredging project was conducted in 1974-1990 to decrease the Hg levels in sediments below $25 \mathrm{mg} / \mathrm{kg}$ by removing contaminated sediments and soil washing. As a result, the $\mathrm{Hg}$ level was reduced from 2000 to less than $10 \mathrm{mg} / \mathrm{kg}$ [71,72], which is considerably lower than the sediment $\mathrm{Hg}$ level in the Nura River (9.95-306 mg/kg, [61]). These measures have also led to a decrease of $\mathrm{Hg}$ content of water (total $\mathrm{Hg}$ of 1.3-4.3 ng/L, [71]), which are 1000 times lower than peak $\mathrm{Hg}$ concentrations in water of the Nura River during floods [61].

Two other aldehyde production sites polluted with Hg are Schkopau, Germany, and Guizhou, China. Both of these sites exhibit extremely elevated $\mathrm{Hg}$ level in the soil close to the plant (over $1000 \mathrm{mg} / \mathrm{kg}$ in Germany [51] and around $300 \mathrm{mg} / \mathrm{kg}$ in China [74-76], which are relatively lower than the maximum value reported for the Nura River (1974 mg/kg [66]). Out of all presented cases, the contaminated site in China is the most comparable to the one reviewed in this paper. The acetaldehyde plant also discharged $\mathrm{Hg}$-containing wastewater into the river, and its polluted water (total $\mathrm{Hg}$ up to $1830 \mathrm{ng} / \mathrm{L}$ [75] was used for agricultural purposes, namely for irrigation of rice fields, leading to human exposure to $\mathrm{Hg}$ in both rice and fish from the river. Despite a large disparity in estimated $\mathrm{Hg}$ releases of these two facilities, both river systems had similar $\mathrm{Hg}$ concentrations in water.

$\mathrm{Hg}$ levels in some media show substantial reduction compared to previously reported values such as in the cases of the contaminated river near a Hg-cell chlor-alkali plant post-closure in New Brunswick, Canada [87] and Minamata Bay (Japan) close to an acetaldehyde plant after a massive dredging project [69-71]. However, all of the studies mentioned in Table 4 report concerns associated with one or several of the following: wet and dry deposition of $\mathrm{Hg}$ in soils, a potential re-release of $\mathrm{Hg}$ from sinks including soils and sediments, leaching from wastes disposed on the plants' territory, and bioaccumulation of $\mathrm{Hg}$ in the site's biota. There are increasingly more reported cases of $\mathrm{Hg}$ pollution resulting from operations of chlor-alkali (e.g., Sagua La Grande, Cuba [95,96]; Angara River, Russia [97]; Neratovice, Czech Republic [98]) and aldehyde plants (e.g., Ravenna, Italy [99]) worldwide indicating how prevailing is the problem. They also demonstrate the value in reporting the current situation and sharing lessons learned in environmental assessment, risk characterization, and remediation responses of all individual cases.

\section{Remediation Responses}

Elemental inorganic contaminants such as $\mathrm{As}, \mathrm{Cd}, \mathrm{Cr}, \mathrm{Cu}, \mathrm{Hg}, \mathrm{Mn}, \mathrm{Ni}, \mathrm{Pb}, \mathrm{Ti}$, and $\mathrm{Zn}$, are not degradable in the environment, and therefore, their remediation generally involves their removal or 
immobilization (Table 5). Several programs of demercuration of the contaminated sites in Kazakhstan were launched, but their completion level is uncertain, and their effectiveness was not adequately evaluated. Both the literature and the present review address certain further remediation alternatives; however, it should be noted that these should be validated based on the latest field data and pilot-scale laboratory tests before their implementation. Table 5 and Figure 3 present remediation technologies for different media including but not limited to those applicable to the Hg-contaminated zones in Kazakhstan.

A wide variety of $\mathrm{Hg}$ remediation technologies are available for different media (soil, water, air, waste), which could be categorized into main groups in terms of removal mechanism: physical, physio-chemical, chemical, and biological (Figure 3) [100]. Some of the techniques are established and thus have been used on contaminated sites for a long time, whereas others are still in the stage of development and testing. As each of these methods has its own advantages and limitations, an appropriate selection is only possible after a thorough investigation of the $\mathrm{Hg}$-contaminated site since a lot of factors must be considered. These include the type of contaminated media, $\mathrm{Hg}$ speciation and concentrations, soil properties, environmental conditions, budget, and proximity to settlements.

Regarding emerging technologies, recent reviews point out nanotechnologies and the use of synthetic materials for $\mathrm{Hg}$ adsorption-innovative materials developed to enhance selected parameters including surface area and porosity [101]. This technology, depending on the material selection, can be applied for heavy metals removal from water, soil, and air; many studies reporting high adsorption values [101,102]. Another promising removal method seems to be phytoremediation of $\mathrm{Hg}$ from contaminated soils (via for instance, Brassica juncea (Indian mustard), Jatropha curcas, Polypogon monspeliensis (beard grass) [100]). It is found to be a safe, inexpensive, ecologically safe, and efficient demercuration method [103].

In order to increase the removal value and cost efficiency of remediation techniques (Table 5), inventions have been proposed. For example, while conventional microbiological treatment involves several steps aimed to reduce $\mathrm{Hg}$ (II) to $\mathrm{Hg}(0)$, a new proposed method ("Microbiological Mercury Removal from Contaminated Materials") [104] offers a single-step treatment by a culture of microorganisms belonging to the genus Bacillus. This allows the removal of a broad group of $\mathrm{Hg}$ compounds (organic and inorganic) while omitting the pretreatment stage of leaching the $\mathrm{Hg}$ with chemical compounds. Moreover, Lestan et al. [105] invented a batch process, compared to conventional soil washing, providing advantages in the removal of alkaline precipitation of toxic metals hydroxides including $\mathrm{Hg}$ due to the alkaline adsorption of polysaccharides adsorbents. This eliminates the necessity of further cleansing of process waters; and in addition, allows the reuse of Ca-containing base and polysaccharides adsorbent which significantly decreases the generation of waste materials. Another technique introduced by Alden et al. [106], which can be implemented in situ and applicable for industrial pollution cases, ("Method and a Chemical Composition for Accelerated In-Situ Biochemical Remediation") proposes the acceleration of the subsoil matter reduction by addition of a mixture comprising ferrous sulfide followed by the addition of organic hydrogen donor, which creates anaerobic conditions for bacteria to biodegrade residual contaminants. A final example regarding stabilization/solidification remediation technologies is a novel method ("Stabilisation curing agent and administering method that heavy-metal contaminated soil or solid waste are administered") that uses a mix of magnesia, sulfur-based, and silicon-based compounds to provide long-term stabilization effect to various heavy metals compounds including Hg [107]. The proposed remediation technology, in comparison to the conventional method, minimizes the probability of solidified agents to re-dissolve within the contaminated matrix. 


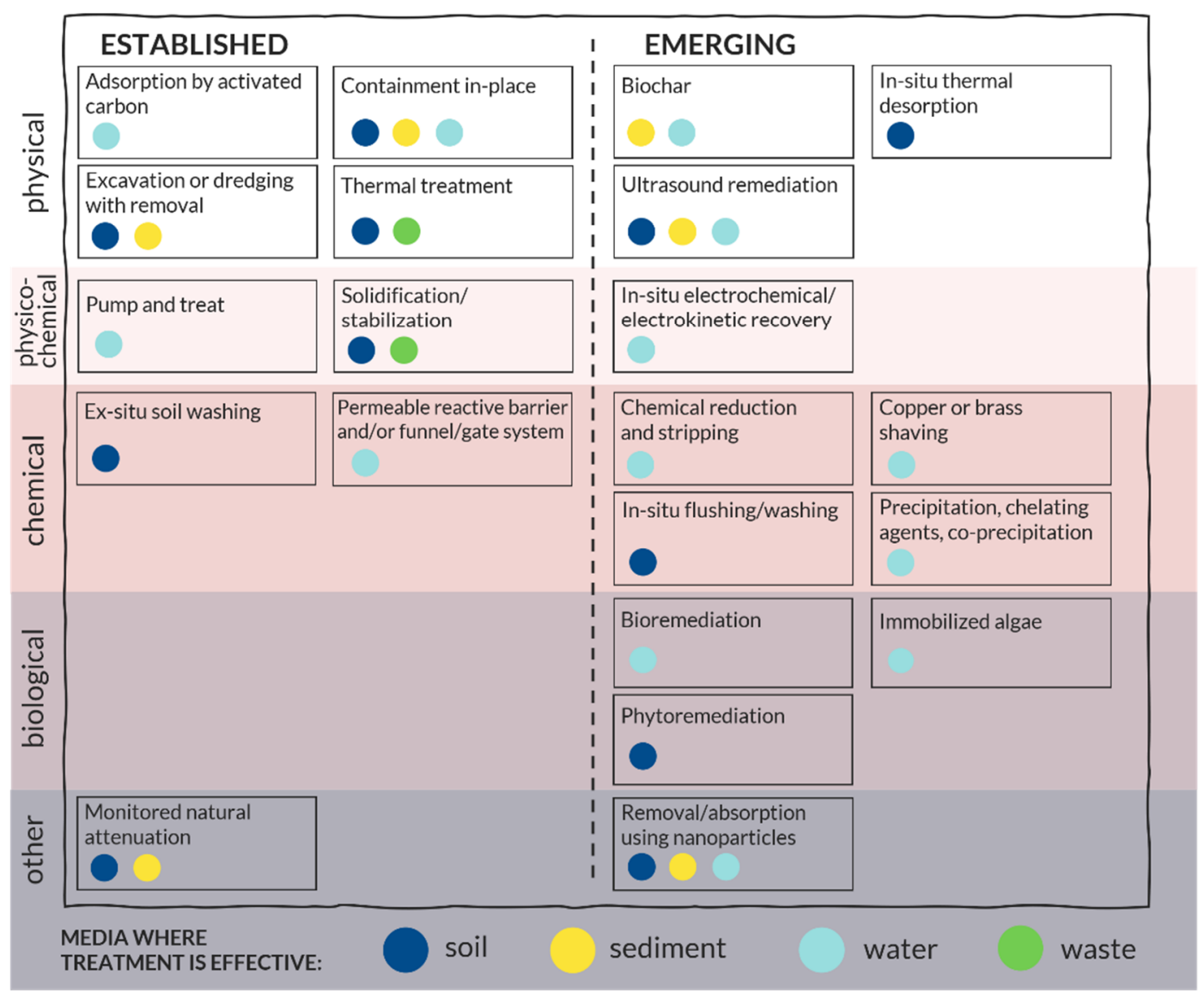

Figure 3. Established and emerging remediation technologies for $\mathrm{Hg}$-contaminated zones. 
Table 5. Selected reviewed remediation technologies.

\begin{tabular}{|c|c|c|c|c|}
\hline Remediation/Treatment Technology & Media & Description & Removal Values & References \\
\hline Adsorption by activated carbon & Water & $\begin{array}{l}\text { A universal adsorbent material to reduce flux to } \\
\text { the environment }\end{array}$ & $60-95 \%$ & {$[6,100,108]$} \\
\hline Biochar & Sediment, Water & $\begin{array}{l}\text { Sorption of the contaminant by biochar-charcoal } \\
\text { produced from plant matter }\end{array}$ & up to $95 \%$ in pore water & {$[48,102]$} \\
\hline $\begin{array}{l}\text { Bioremediation: bio-treatment, } \\
\text { biofunctionalized zeolite, genetically } \\
\text { engineered bacteria }\end{array}$ & Water & $\begin{array}{l}\text { A process that generally utilizes microorganisms, } \\
\text { plants, or their enzymes to decrease the toxicity of } \\
\text { the contaminant }\end{array}$ & $91-95 \%$ & {$[6,109,110]$} \\
\hline Chemical reduction and stripping & Water & $\begin{array}{l}\text { Injecting chemically reductive additives into } \\
\text { contaminated media/chemical reductant in the } \\
\text { contaminant plume; physical separation from the } \\
\text { aquatic stream by vapor }\end{array}$ & $>94 \%$ & {$[100,102,111]$} \\
\hline Containment in-place & Soil, Sediment, Water & $\begin{array}{l}\text { Covering contaminated media with clean soil } \\
\text { and/or other low permeability material }\end{array}$ & not applicable & {$[6,112]$} \\
\hline Copper or brass shavings & Water & Removal of $\mathrm{Hg}_{2+}$ from water by the amalgamation & $96-98 \%$ & {$[48,113,114]$} \\
\hline Ex situ soil washing & Soil & $\begin{array}{l}\text { Washing the excavated soils with a special } \\
\text { solution, scrubbing, and separating clean soil }\end{array}$ & up to $99 \%$ & {$[6,100,115]$} \\
\hline Excavation or dredging with removal & Soil, Sediment & $\begin{array}{l}\text { Removal and off-site storage of the contaminated } \\
\text { material }\end{array}$ & not applicable & {$[48,116]$} \\
\hline Immobilized algae & Water & $\begin{array}{l}\text { Accumulation of the contaminant from aquatic } \\
\text { media in certain species of algae }\end{array}$ & up to $90 \%$ & {$[100,102,117]$} \\
\hline In situ thermal desorption & Soil & $\begin{array}{l}\text { On-site heating soil to very high temperatures to } \\
\text { release contaminant in gaseous/vapor phase }\end{array}$ & $99 \%$ & {$[6,112,118]$} \\
\hline In situ flushing/washing & Soil & $\begin{array}{l}\text { Flooding a zone with a flushing solution to } \\
\text { mobilize contaminant }\end{array}$ & $35-90 \%$ & {$[50,112]$} \\
\hline $\begin{array}{l}\text { In situ electrochemical/electrokinetic } \\
\text { recovery }\end{array}$ & Soil & $\begin{array}{l}\text { Applying low-intensity direct current across } \\
\text { electrodes to drive ions migration to the opposite } \\
\text { sign electrode using a mobilizing solution }\end{array}$ & $30-92 \%$ & {$[102,112]$} \\
\hline Monitored natural attenuation & Soil, Sediment & $\begin{array}{l}\text { Natural physio-chemical/biological processes } \\
\text { reduce concentration/toxicity/mobility }\end{array}$ & not applicable & {$[6,116]$} \\
\hline
\end{tabular}


Table 5. Cont.

\begin{tabular}{|c|c|c|c|c|}
\hline Remediation/Treatment Technology & Media & Description & Removal Values & References \\
\hline Nanotechnology & Soil, Sediment, Water & $\begin{array}{l}\text { Injected FeS nanoparticles to contaminated soil } \\
\text { immobilize } \mathrm{Hg} \text { via ion exchange/adsorption }\end{array}$ & $\sim 92 \% \mathrm{Ag}-\mathrm{Zn}>99 \%$ & {$[102,109,112]$} \\
\hline $\begin{array}{l}\text { Permeable reactive barrier and/or } \\
\text { funnel/gate system }\end{array}$ & Water & $\begin{array}{l}\text { A subsurface construction used to channel the } \\
\text { contaminated plume into a gate with reactive } \\
\text { material to adsorb/decompose/transform the } \\
\text { contaminant }\end{array}$ & $\begin{array}{l}\text { variable (material- and } \\
\text { site-specific) }\end{array}$ & [119] \\
\hline $\begin{array}{l}\text { Phytoremediation (phytostabilization, } \\
\text { phytoextraction, phytovolatilization) }\end{array}$ & Soil & $\begin{array}{l}\text { A process that uses plants to remove, stabilize, or } \\
\text { destroy the contaminant }\end{array}$ & $\begin{array}{l}>99 \%, 2.62 \mathrm{mg} / \mathrm{kg} \max \\
\text { removal efficiency }\end{array}$ & $\begin{array}{l}{[100,103,116,} \\
120]\end{array}$ \\
\hline $\begin{array}{l}\text { Precipitation, co-precipitation, } \\
\text { chelating agents }\end{array}$ & Water & $\begin{array}{l}\text { A chelating reagent is added to the contaminated } \\
\text { water in soluble form, and the contaminant is } \\
\text { removed after its flocculation and/or precipitation }\end{array}$ & variable (reagent-specific) & {$[111,121]$} \\
\hline Pump and treat & Water & $\begin{array}{l}\text { Pumping contaminated groundwater to treatment } \\
\text { system, discharging back to environment }\end{array}$ & $\begin{array}{l}\text { variable (technology } \\
\text { specific) }\end{array}$ & [112] \\
\hline Solidification/Stabilization & Soil, Waste & $\begin{array}{l}\text { Physically encapsulating or chemically stabilizing } \\
\text { the contaminant in the soil }\end{array}$ & $90-98 \%$ & {$[6,109,112]$} \\
\hline $\begin{array}{l}\text { Thermal treatment: (1) batch } \\
\text { retorting, (2) ex situ thermal } \\
\text { desorption, (3) vitrification }\end{array}$ & Soil, Waste & $\begin{array}{l}\text { (1) Heating contaminated material under vacuum } \\
\text { to volatilize Hg volatilization, (2) heating } \\
\text { excavated soil for volatilization, (3) melting and } \\
\text { cooling soils to immobilize contaminant }\end{array}$ & up to $99 \%$ & {$[6,109,122]$} \\
\hline Ultrasound remediation & Soil, Sediment, Water & $\begin{array}{l}\text { High ultrasonic sound }(150-2000 \mathrm{kHz}) \text { leading to } \\
\text { desorption produced by local turbulence and/or to } \\
\text { degradation due to free radical oxidation reactions }\end{array}$ & $\begin{array}{l}\sim 5 \% \text {, usually used with } \\
\text { bioremediation }\end{array}$ & [123] \\
\hline
\end{tabular}




\subsection{Demercuration of Lake Balkyldak}

The U.S. EPA financially supported the demercuration plan of Lake Balkyldak and PCP territory and initially included the following: (1) dismantling the electrolysis factory, (2) constructing an underground landfill for disposing of uncontaminated demolished construction waste and other hazardous wastes of Class IV (flammable solids, spontaneously combustible substances and water-reactive), (3) excavation and soil washing, (4) constructing a "cut-off wall" around the territory of $\mathrm{PCP}$ to prevent further spread of $\mathrm{Hg}$, and (5) excavating the concrete floors of the former facility followed by its thermal treatment [59]. However, due to limited investment, only the following steps were completed: (1) "cut-off wall" of total length 3588 m constructed; (2) the contaminated topsoils were excavated and isolated with the cut-off walls; (3) the hotspots (over 180,000 $\mathrm{m}^{2}$ ) were covered with clay; (4) the shop for Hg electrolysis was dismantled and disposed of in a special cell, then stabilized with cement and covered with asphalt layer; (5) a monolithic storage facility was constructed. According to the report on the development programs of Pavlodar city for 2016-2020 [124], the design specifications and estimates for the construction of an anti-filtration dam from the west side of the former pumping station to Balkyldak reservoir were developed for further implementation. Because the demercuration measures were limited to confinement actions, large quantities of $\mathrm{Hg}$ remained on the territory, dispersed in various media: soil, groundwater, and the lake's surface water and sediments; thus, further demercuration is strongly recommended [63].

The media with the highest $\mathrm{Hg}$ content are soils of the plant's territory and sediments of Lake Balkyldak near the outfall; therefore, the recommended remediation methods are directed primarily to these areas. Moreover, since the contamination was generally considered as localized, cost-effective containment strategies might be preferred over more complex removal methods. However, initially planned ex situ soil washing and thermal treatment of the concrete waste have not yet been performed. After completing the post-containment management and monitoring of $\mathrm{Hg}$ pollution on the $\mathrm{PCP}$ site in 2005-2009, Ilyushchenko et al. [63] suggested soil pulping and gravitational separation of elemental $\mathrm{Hg}$ as an option for soil remediation. As an alternative to containment, Ullrich et al. [50] suggested applying the combination of ultrasound and transgenic algae to treat the sediments, and according to preliminary trial results, ultrasound treatment achieved $>95 \%$ efficiency in $\mathrm{Hg}$ removal. Electrokinetics (Table 5) might also be suggested as an alternative soil remediation technology (currently at the testing stage) for inorganic $\mathrm{Hg}$ species since it can be applied to all soil types, does not require excavation, can remove other contaminants, and is relatively inexpensive [112].

\subsection{Demercuration of Nura River}

Starting from the 1950s, the acetaldehyde factory in Temirtau discharged untreated wastewater containing Hg directly to Nura River, and only beginning in 1977, Hg-rich sludge had been allegedly neutralized, sulfidized, and magnetically treated before being discharged. This treatment system for contaminated wastewater was based on sulfide precipitation and reduced only metallic and some fraction of ionic $\mathrm{Hg}$, but not organic $\mathrm{Hg}$. In 1980, the aldehyde facility was under reconstruction, and the wastewater treatment system was dismantled. Clean-up of the Nura River Project is a joint project subsidized by the Government of Kazakhstan and the International Bank for Reconstruction and Development was conducted in 2004-2011 with the total project cost initially estimated at 67.82 million USD but increased to 97.42 million USD [125]. The results were rated as "satisfactory»: "Carbide" facility was demolished, all metallic $\mathrm{Hg}$ was immobilized and/or collected; the factory's foundation and contaminated soil were landfilled. The cleanup project's goal was to decrease $\mathrm{Hg}$ content in the river water downstream of the Intumak reservoir (Figure 1), and the target value of 50-120 ng/L in surface waters was achieved. A hazardous waste landfill for disposing of $\mathrm{Hg}$-contaminated soil and sediment was constructed in 2010: the landfill received more than 1 million $\mathrm{m}^{3}$ of contaminated material [125]. However, according to Dushkina et al. [126], in 2014, the total Hg emissions to Kazakhstan's environment were estimated to be $577,000 \mathrm{~kg}$. The quality monitoring of the Nura River 
surface waters in 2017 showed that the maximum permissible concentration for $\mathrm{Hg}$ of $10 \mathrm{ng} / \mathrm{L}$ was exceeded in 17 out of 25 samples with a peak concentration of $4800 \mathrm{ng} / \mathrm{L}$ [126].

As mentioned in Section 4, the contaminant in the river is naturally diluted and may recover from the contamination faster if the $\mathrm{Hg}$ discharge ceases. One of the critical sections in terms of $\mathrm{Hg}$-contaminated soil and sediments is the first $10-20 \mathrm{~km}$ from the wastewater discharge point because it also affects Nura River's water. There is a lack of the reported Hg concentrations from the last ten years, so before developing and implementing a more effective demercuration project, a detailed analysis of the region's soil, sediments and water is highly recommended.

Removing contaminated silt deposits and topsoils from the riverbanks and controlling wastewater discharge are highly recommended actions that can be taken to demercurate the region $[54,55,66]$. It was also recommended to rebuild a reservoir as a settling basin on Intumak as planned initially and reduce the spring floods that cause sediment disturbance [66]. Other contamination regulation actions may include $\mathrm{Hg}$ isolation by stockpiling silts under a thick layer $(1 \mathrm{~m})$ of inert cover material in a location safe from groundwater intrusion and flooding, removing and isolating the upper $40 \mathrm{~cm}$ of highly contaminated soil from Zhaur Swamp, and prohibiting the use of soils with $\mathrm{Hg}$ higher than $10 \mathrm{mg} / \mathrm{kg}$ for agricultural purposes.

\section{Conclusions and Recommendations}

The current paper presented a detailed review of Hg-contaminated sites (two former industrial sites) in Kazakhstan, including a comparison with the literature and a review of remediation alternatives. It aims not only to provide a critical update regarding the situation with these sites but also to serve as a resource for similar global Hg-contaminated sites that might assist in their assessment, rehabilitation, and management. Regarding the first site (Lake Balkyldak site), it can be concluded that the chlor-alkali plant, which stopped operating more than 30 years ago after having discharged hundreds of tons of mercury $(\mathrm{Hg})$ to the environment, seriously affected the region and negatively impacted the health of the people from Pavlodar region and nearby villages.

- Sediments from Lake Balkyldak are severely contaminated in contrast to the nearby Irtysh River, which was less affected by $\mathrm{Hg}$ pollution.

- Several hotspots with high Hg levels, mainly located on the chemical plant's territory, might still be significant sources of pollution, and as a result, $\mathrm{Hg}$ from soil can affect the atmosphere, groundwater, and other media.

- Human health risks are mainly related to fish consumption from the lake and homegrown vegetables with the possibility of soil ingestion.

Regarding the second site (Nura River site), it can be concluded that the acetaldehyde production plant, which was closed more than 20 years ago, left a significant negative mark on the ecosystem of Central Kazakhstan and the public health of the local population in the form of $\mathrm{Hg}$ pollution of Nura River and Samarkand and Intumak reservoirs. The contamination was significant and mainly localized, with the majority of $\mathrm{Hg}$ deposited in topsoils and riverbank deposits within $25 \mathrm{~km}$ from the discharge point.

- The first 10-20 km of the riverbed from the wastewater discharge point was confirmed to be the most contaminated part of the river in terms of $\mathrm{Hg}$ in soil, sediments, and technogenic silts.

- Special attention should be paid to the river sediments that may contaminate water during annual floods.

- The local population might be exposed to $\mathrm{Hg}$ due to the consumption of locally caught fish from the river and reservoirs; hence, it is necessary to prohibit fishing and consumption in the region.

It is necessary to mention a deficit of the relevant recent follow-up studies, so further research of the area is recommended to verify the previous findings and assess the current situation. Overall, 
the review of available literature showed significant gaps in terms of recent investigations and a lack of integrated site assessment. Moreover, both sites seem to be in need of further remediation action. The suggested potential remediation responses include removing contaminated silts from the Nura riverbanks whereas multiple alternatives seem to be present for Lake Balkyldak from soil washing to electrokinetic remediation. However, the recommendations are preliminary, and these techniques need to be validated based on the latest field data and on pilot-scale laboratory experiments. It has been established that cities and surrounding territories of Temirtau and Pavlodar are still Hg-contaminated regions because of the persisting impact of former acetaldehyde and chlor-alkali plants. As the literature is fragmented, fails to provide complete information on $\mathrm{Hg}$ pollution in the regions, indicates the persistence of contamination, and presents data which is now outdated, a comprehensive site characterization effort is necessary to establish an up-to-date picture of the current situation for both sites.

Author Contributions: Conception: M.G., Z.A., A.K., V.I., F.K.; Literature review: Z.A., A.K., S.K., A.S., Writing: M.G., Z.A., A.K., K.B., S.K., F.K.; Editing: M.G., Z.A., A.K., K.B., F.K.; Project management: M.G., F.K.; Funding: M.G., V.I., F.K. All authors have read and agreed to the published version of the manuscript.

Funding: This research was funded by Nazarbayev University (under the project titled «Mercury contamination in Pavlodar and Borovoe, Kazakhstan: Evaluation of atmospheric emissions and cycle systems, site assessment, and human health risk characterization») via the Faculty Development Competitive Research Grant Program (FDCRGP) with funder project reference: 090118FD5319. The APC was funded by the same program.

Acknowledgments: The authors would like to thank the reviewers for their valuable comments on the manuscript.

Conflicts of Interest: The authors declare no conflict of interest.

\section{References}

1. EEA (European Environment Agency). Hazardous Substances in Europe's Fresh and Marine Waters-An Overview; EEA Technical Report No 8/2011; EEA: Copenhagen, Denmark, 2011.

2. UNEP (United Nations Environmental Protection) and WHO (World Health Organization). Guidance for Identifying Populations at Risk from Mercury Exposure; UNEP (United Nations Environmental Protection) and WHO (World Health Organization): Geneva, Switzerland, 2008.

3. Hsiao, H.-W.; Ullrich, S.M.; Tanton, T.W. Burdens of mercury in residents of Temirtau, Kazakhstan. Sci. Total Environ. 2011, 409, 2272-2280. [CrossRef] [PubMed]

4. Zhu, S.; Chen, B.; He, M.; Huang, T.; Hu, B. Speciation of mercury in water and fish samples by HPLC-ICP-MS after magnetic solid phase extraction. Talanta 2017, 171, 213-219. [CrossRef] [PubMed]

5. Swedish Work Environment Authority. Occupational Exposure Limit Values, AFS 2011:18. The Swedish Work Environment Authority's Provisions and General Recommendations on Occupational Exposure Limit Values. 2011. Available online: https://old.liu.se/medfak/bkv/arbetsmiljo/laboratoriesakerhetshandboken/ kemikaliehantering/forbud-och-tillstand/dokument-om-om-forbud-gransvarden-mm/1.692615/ OccupationalExposureLimitValues_AFS2011_18.Eng.pdf (accessed on 30 November 2020).

6. Xu, J.; Bravo, A.G.; Lagerkvist, A.; Bertilsson, S.; Sjöblom, R.; Kumpiene, J. Sources and remediation techniques for mercury contaminated soil. Environ. Int. 2015, 74, 42-53. [CrossRef] [PubMed]

7. Bueno, P.C.; Bellido, E.; Rubí, J.A.M.; Ballesta, R.J. Concentration and spatial variability of mercury and other heavy metals in surface soil samples of periurban waste mine tailing along a transect in the Almadén mining district (Spain). Environ. Earth Sci. 2008, 56, 815-824. [CrossRef]

8. Zhu, W.; Li, Z.; Li, P.; Yu, B.; Lin, C.-J.; Sommar, J.; Feng, X. Re-emission of legacy mercury from soil adjacent to closed point sources of Hg emission. Environ. Pollut. 2018, 242, 718-727. [CrossRef] [PubMed]

9. Tasca, A.L.; Puccini, M. Leather tanning: Life cycle assessment of retanning, fatliquoring and dyeing. J. Clean. Prod. 2019, 226, 720-729. [CrossRef]

10. AMAP (Arctic Monitoring and Assessment Programme)/UNEP (United Nations Environment Programme). Technical Background Report for the Global Mercury Assessment 2013; UNEP: Geneva, Switzerland, 2013.

11. Qureshi, A.; MacLeod, M.; Scheringer, M.; Hungerbühler, K. Mercury cycling and species mass balances in four North American lakes. Environ. Pollut. 2009, 157, 452-462. [CrossRef] [PubMed] 
12. Acquavita, A.; Biasiol, S.; Lizzi, D.; Mattassi, G.; Pasquon, M.; Skert, N.; Marchiol, L. Gaseous Elemental Mercury Level and Distribution in a Heavily Contaminated Site: The Ex-chlor Alkali Plant in Torviscosa (Northern Italy). Water Air Soil Pollut. 2017, 228, 62-75. [CrossRef]

13. O'Connor, D.; Hou, D.; Ok, Y.S.; Mulder, J.; Duan, L.; Wu, Q.; Wang, S.; Tack, F.M.; Rinklebe, J. Mercury speciation, transformation, and transportation in soils, atmospheric flux, and implications for risk management: A critical review. Environ. Int. 2019, 126, 747-761. [CrossRef] [PubMed]

14. WHO (World Health Organization). Guidelines for Drinking-Water Quality, 3rd ed.; WHO: Geneva, Switzerland, 2004; Volume 1, Available online: http://www.who.int/water_sanitation_health/dwq/GDWQ2004web.pdf (accessed on 30 November 2020).

15. Covelli, S.; Faganeli, J.; Horvat, M.; Brambati, A. Porewater Distribution and Benthic Flux Measurements of Mercury and Methylmercury in the Gulf of Trieste (Northern Adriatic Sea). Estuar. Coast. Shelf Sci. 1999, 48, 415-428. [CrossRef]

16. Guney, M.; Welfringer, B.; De Repentigny, C.; Zagury, G.J. Children's Exposure to Mercury-Contaminated Soils: Exposure Assessment and Risk Characterization. Arch. Environ. Contam. Toxicol. 2013, 65, 345-355. [CrossRef] [PubMed]

17. Goldman, L.R.; Shannon, M.W. The Committee on Environmental Health Technical report: Mercury in the environment: Implications for pediatricians. Pediatrics 2001, 108, 197-205. [CrossRef] [PubMed]

18. Bozheyeva, G. The Pavlodar chemical weapons plant in Kazakhstan: History and legacy. Nonproliferation Rev. 2000, 7, 136-145. [CrossRef]

19. Woodruff, S.; Dack, S. Analysis of risk from mercury contamination at the Khimprom Plant in Kazakhstan. Land Contam. Reclam. 2004, 12, 213-218. [CrossRef]

20. Ilyushchenko, M.A.; Yakovlyeva, L.V.; Heaven, S.; Lapshin, E.V. Mercury pollution in Nura River. Promyshlennost Kazakhstana 2001, 6, 56-59. (In Russian)

21. Hsiao, H.-W.; Ullrich, S.M.; Tanton, T.W. Burdens of mercury in residents of Temirtau, KazakhstanII: Verification of methodologies for estimating human exposure to high levels of $\mathrm{Hg}$ pollution in the environment. Sci. Total Environ. 2010, 408, 4033-4044. [CrossRef]

22. Tanton, T.W.; Ilyushchenko, M.A.; Heaven, S. Some water resources issues of Central Kazakhstan. Proc. Inst. Civ. Eng.-Water Marit. Eng. 2001, 148, 227-233. [CrossRef]

23. EC (European Council). Directive 2000/60/EC of the European Parliament and the Council. L327; EC: Brussels, Belgium, 2000.

24. EC (European Council). Directive 2008/105/EC of the European Parliament and of the Council of 16 December 2008 on Environmental Quality Standards in the Field of Water Policy; EC: Brussels, Belgium, 2008.

25. Chan, H.M. Mercury in fish: Human health risks. In Encyclopedia of Environmental Health; Nriagu, J.O., Ed.; Elsevier: Burlington, NY, USA, 2011; pp. 697-704.

26. Shao, D.; Liang, P.; Kang, Y.; Wang, H.-S.; Cheng, Z.; Wu, S.; Shi, J.; Lo, S.C.L.; Wang, W.; Wong, M.H. Mercury species of sediment and fish in freshwater fish ponds around the Pearl River Delta, PR China: Human health risk assessment. Chemosphere 2011, 83, 443-448. [CrossRef]

27. Calvo, A.C.; Cutanda, F.; Esteban, M.; Pärt, P.; Navarro, C.; Gómez, S.; Rosado, M.; Lopez, A.M.R.; López, E.; Exley, K.; et al. Fish consumption patterns and hair mercury levels in children and their mothers in $17 \mathrm{EU}$ countries. Environ. Res. 2015, 141, 58-68.

28. Morel, F.M.M.; Kraepiel, A.M.L.; Amyot, M. The chemical cycle and bioaccumulation of mercury. Annu. Rev. Ecol. Syst. 1998, 29, 543-566. [CrossRef]

29. OSHA (Occupational Safety and Health Administration). 2020. Available online: https://www.osha.gov/ SLTC/mercury/index.html (accessed on 14 April 2020).

30. ATSDR (Agency for Toxic Substances and Disease Registry). Toxicological Profile for Mercury; ATSDR: Atlanta, GA, USA, 1999.

31. Leal, L.T.C.; Guney, M.; Zagury, G.J. In vitro dermal bioaccessibility of selected metals in contaminated soil and mine tailings and human health risk characterization. Chemosphere 2018, 197, 42-49. [CrossRef]

32. U.S. EPA (United States Environmental Protection Agency). Integrated Risk Information System (IRIS) Mercury, Elemental Quickview. 1995. Available online: https:/cfpub.epa.gov/ncea/iris2/chemicalLanding. cfm?\&substance_nmbr=370 (accessed on 17 April 2020). 
33. U.S. EPA (United States Environmental Protection Agency). Integrated Risk Information System (IRIS) Mercuric Chloride $\left(\mathrm{HgCl}_{2}\right)$ Quickview. 1995. Available online: https://cfpub.epa.gov/ncea/iris2/ chemicalLanding.cfm?substance_nmbr=692 (accessed on 17 April 2020).

34. U.S. EPA (United States Environmental Protection Agency). Integrated Risk Information System (IRIS) Methylmercury (MeHg). 2001. Available online: https://cfpub.epa.gov/ncea/iris2/chemicalLanding.cfm? \&substance_nmbr=73 (accessed on 17 April 2020).

35. Ministry of National Economy. Order of the Minister of National Economy of the Republic of Kazakhstan Dated February 28 2015. No. 168 "On Approval of Hygienic Standards for Atmospheric Air in Urban and Rural Settlements"; Ministry of National Economy of the Republic of Kazakhstan: Nur-Sultan, Kazakhstan, 2015. (In Russian)

36. WHO (World Health Organization). Air Quality Guidelines for Europe; World Health Organization Regional Office for Europe: Denmark, Copenhagen, 2000.

37. U.S. EPA (United States Environmental Protection Agency). 2018 Edition of the Drinking Water Standards and Health Advisories; U.S. EPA: Washington, DC, USA, 2018.

38. FPT CDW (Federal-Provincial-Territorial Committee on Drinking Water). Guidelines for Canadian Drinking Water Quality—Summary Table; FPT CDW: Ottawa, ON, Canada, 2010.

39. EC (European Council). Council Directive 98/83/EC of 3 November 1998 on the Quality of Water Intended for Human Consumption; EC: Brussels, Belgium, 1998.

40. Ministry of National Economy. Order of the Minister of National Economy of the Republic of Kazakhstan dated March 16, 2015 No. 209 “On Approval of the Sanitary Rules 'Sanitary and Epidemiological Requirements for Water Sources, Places for Water Intake for Household and Drinking Purposes, Domestic and Drinking Water Supply and Places for Cultural and Domestic Water Use and the Safety of Water Bodies'"; Ministry of National Economy of the Republic of Kazakhstan: Nur-Sultan, Kazakhstan, 2015. (In Russian)

41. DTSC (California Department of Toxic Substances Control) and HERO (Human and Ecological Risk Office). HERO Human Health Risk Assessment (HHRA) Note 3, DTSC-Modified Screening Levels (DTSC-SLs). 2019. Available online: https://dtsc.ca.gov/wp-content/uploads/sites/31/2019/04/HHRA-Note-3-2019-04.pdf (accessed on 30 November 2020).

42. CCME (Canadian Council of Ministers of the Environment). Canadian soil quality guidelines for the protection of environmental and human health: Mercury (inorganic) (1999). In Canadian Environmental Quality Guidelines, 1999; Canadian Council of Ministers of the Environment: Winnipeg, MB, Canada, 1999.

43. Lame, F.; Maring, L. Into Dutch Soils; Ministry of Infrastructure and the Environment of The Netherlands: Brussels, Belgium, 2014.

44. Ministry of National Economy. Order of the Minister of National Economy of the Republic of Kazakhstan dated June 25, 2015 No. 452 “On Approval of Hygienic Standards for Environmental Safety (Soil)"; Ministry of National Economy of the Republic of Kazakhstan: Nur-Sultan, Kazakhstan, 2015. (In Russian)

45. Zillioux, E.J. Mercury in Fish: History, Sources, Pathways, Effects, and Indicator Usage. Environ. Indic. 2015, 743-766.

46. Ministry of Health. Order of the Acting Minister of Health of the Republic of Kazakhstan dated August 6, 2010 No. 611 "On Approval of Sanitary Rules Sanitary and Epidemiological Requirements for Food Products"; Ministry of Health of the Republic of Kazakhstan: Nur-Sultan, Kazakhstan, 2010. (In Russian)

47. Neculita, C.M.; Zagury, G.J.; Deschênes, L. Mercury speciation in highly contaminated soils from chlor-alkali plants using chemical extractions. J. Environ. Qual. 2005, 34, 255-262. [PubMed]

48. Eckley, C.S.; Gilmour, C.C.; Janssen, S.; Luxton, T.P.; Randall, P.M.; Whalin, L.; Austin, C. The assessment and remediation of mercury contaminated sites: A review of current approaches. Sci. Total Environ. 2020, 707, 136031. [CrossRef]

49. Guney, M.; Karatas, T.; Ozkul, C.; Akyol, N.H.; Acar, R.U. Contamination by As, Hg, and Sb in a region with geogenic As anomaly and subsequent human health risk characterization. Environ. Monit. Assess. 2019, 192, 50. [CrossRef]

50. Ullrich, S.M.; Ilyushchenko, M.A.; Kamberov, I.M.; Tanton, T.W. Mercury contamination in the vicinity of a derelict chlor-alkali plant. Part I: Sediment and water contamination of Lake Balkyldak and the River Irtysh. Sci. Total Environ. 2007, 381, 1-16. [CrossRef] [PubMed]

51. Beck, H.E.; Zimmermann, N.E.; McVicar, T.R.; Vergopolan, N.; Berg, A.; Wood, E. Present and future Köppen-Geiger climate classification maps at 1-km resolution. Sci. Data 2018, 5, 180214. [CrossRef] 
52. FAO (Food and Agriculture Organization of the United Nations). FAO/UNESCO Soil Map of the World: Central Asia. 1992. Available online: http://www.fao.org/soils-portal/soil-survey/soil-maps-and-databases/ faounesco-soil-map-of-the-world/en/ (accessed on 20 April 2020).

53. Sposito, G. Soil, Encyclopedia Britannica. 2020. Available online: https://www.britannica.com/science/soil/ (accessed on 5 May 2020).

54. Heaven, S. Mercury in the River Nura and its floodplain, Central Kazakhstan: I. River sediments and water. Sci. Total Environ. 2000, 260, 35-44. [CrossRef]

55. Heaven, S.; A Ilyushchenko, M.; Kamberov, I.M.; I Politikov, M.; Tanton, T.W.; Ullrich, S.M.; Yanin, E.P. Mercury in the River Nura and its floodplain, Central Kazakhstan: II. Floodplain soils and riverbank silt deposits. Sci. Total Environ. 2000, 260, 45-55. [CrossRef]

56. Yanin, E.P. Mercury in the Epiphyte-Retained Suspension of the Nura River (Kazakhstan) as an Indicator of Technogenic Pollution. Geol. Geophys. 2000, 41, 1074-1077. (In Russian)

57. Ullrich, S.M.; Ilyushchenko, M.A.; Uskov, G.A.; Tanton, T.W. Mercury distribution and transport in a contaminated river system in Kazakhstan and associated impacts on aquatic biota. Appl. Geochem. 2007, 22, 2706-2734. [CrossRef]

58. Ilyushchenko, M.A.; Uskov, G.A.; Zyryanova, N.A. Mercury (Hg) contamination of fish fauna of Bylkyldak technical pond. KazNU Sci. J. Environ. Ser. 2002, 11, 102-105. (In Russian)

59. Ilyushchenko, M.A.; Lapshin, E.V.; Delibare, A.; Tanton, T.W. Influence of Fly Ash of KarGRES-1 on decrease of risk posed by mercury pollution of the Nura River. Promyshlennost Kazakhstana 2005, 30, 60-63.

60. Panin, M.S.; Geldymamedova, E.A. Ecological and geochemical characteristics of the soils of Pavlodar of the Republic of Kazakhstan. Vestn. TSU 2006, 292, 171-177. (In Russian)

61. Ullrich, S.M.; Ilyushchenko, M.A.; Tanton, T.W.; Uskov, G.A. Mercury contamination in the vicinity of a derelict chlor-alkali plant. Part II: Contamination of the aquatic and terrestrial food chain and potential risks to the local population. Sci. Total Environ. 2007, 381, 290-306. [CrossRef]

62. Shaimardanova, B.H.; Korogod, N.P.; Bigaliyev, A.B.; Assylbekova, G.E. Heavy Metals Accumulation in Children Hair. Novosibirsk State University Bulletin. Ser. Biol. Clin. Med. 2009, 8, 107-111. (In Russian)

63. Ilyushchenko, M.A.; Daukeyev, G.B.; Tanton, T.W. Post-Containment Management And monitoring of Mercury Pollution in site of Former PO 'Khimprom' and Assessment of Environmental Risk Posed by Contamination of Groundwater and Adjacent Water Bodies of the Northern Industrial Area of Pavlodar; JSC Almaty University of Power Engineering and Telecommunications: Almaty, Kazakhstan, 2011; Available online: http://hgpavlodar.narod.ru/ (accessed on 30 November 2020).

64. Shakhova, T.S.; Talovskaya, A.V.; Yazikov, E.G.; Filimonenko, E.A.; Lyapina, E.E. Evaluation of mercury contamination in the vicinity of enterprises of the petrochemical complex in the winter period (based on the example of Pavlodar, Republic of Kazakhstan). Bulletin of the Tomsk Polytechnic University. Geo Assets Eng. 2016, 327, 16-25. (In Russian)

65. Randall, P.; Ilyushchenko, M.A.; Lapshin, E.; Kuzmenko, L. Case study: Mercury pollution near a chemical plant in Northern Kazakhstan. Air Waste Manag. Assoc. 2005, 2, 19-24.

66. Ilyushchenko, M.A.; Abdrashitova, S.A.; Tanton, T.W.; Heaven, S.; Yanin, E.P. Results of research into mercury pollution of the river Nura in Central Kazakhstan and proposals for demercurisation. In Materials of the Second Congress in memory of B.A.Beremzhanov in Chemistry and Chemical Technologies; Chemistry Series; Vestnik KazGU: Almaty, Kazakhstan, 1999; pp. 18-21.

67. Yanin, E.P. Mercury in industrial river sludges: Features of redistribution, location, geochemical mobility. In Proceedings of the Second International Symposium "Mercury in the Biosphere: Ecological and Geochemical Aspects", Novosibirsk, Russia, 21-25 September 2015; pp. 401-406. (In Russian).

68. Hintelmann, H.; Hempel, M.; Wilken, R.D. Observation of Unusual Organic Mercury Species in Soils and Sediments of Industrially Contaminated Sites. Environ. Sci. Technol. 1995, 29, 1845-1850. [CrossRef]

69. Kruger, O.; Ebinghaus, R.; Kock, H.H.; Richter-Politz, I.; Geilhufe, C. Estimation of gaseous mercury emissions in Germany: Inverse modelling of source strengths at the contaminated industrial site BSL Werk Schkopau. In Mercury Contaminated Sites. Environmental Science; Ebinghaus, R., Turner, R.R., de Lacerda, L.D., Vasiliev, O., Salomons, W., Eds.; Springer: Berlin/Heidelberg, Germany, 1999.

70. Hasche, R.L.; Boundy, R.H. Report on Manufacture of Acetaldehyde at I.G. Farbenindustrie; U.S. Technical Intelligence Committee: Schkopau, Germany, 1945. 
71. Tomiyasu, T.; Matsuyama, A.; Eguchi, T.; Marumoto, K.; Ōki, K.; Akagi, H. Speciation of mercury in water at the bottom of Minamata Bay, Japan. Mar. Chem. 2008, 112, 102-106. [CrossRef]

72. Nakata, H.; Shimada,H.; Yoshimoto, M.; Narumi, R.; Akimoto, K.; Yamashita, T.; Matsunaga, T.; Nishimura, K.; Tanaka, M.; Hiraki, K.; et al. Concentrations and Distribution of Mercury and Other Heavy Metals in Surface Sediments of the Yatsushiro Sea including Minamata Bay, Japan. Bull. Environ. Contam. Toxicol. 2007, 80, 78-84. [CrossRef]

73. Matsuyama, A.; Eguchi, T.; Sonoda, I.; Tada, A.; Yano, S.; Tai, A.; Marumoto, K.; Tomiyasu, T.; Akagi, H. Mercury Speciation in the Water of Minamata Bay, Japan. Water, Air Soil Pollut. 2010, 218, 399-412. [CrossRef]

74. Yasuda, Y.; Matsuyama, A.; Yasutake, A.; Yamaguchi, M.; Aramaki, R.; Xiaojie, L.; Pin, J.; Yumin, A.; Li, L.; Mei, L.; et al. Mercury distribution in farmlands downstream from an acetaldehyde producing chemical company in Qingzhen City, Guizhou, People's Republic of China. Bull. Environ. Contam. Toxicol. 2004, 72 , 445-451. [CrossRef]

75. Horvat, M.; Nolde, N.; Fajon, V.; Jereb, V.; Logar, M.; Lojen, S.; Jaćimović, R.; Falnoga, I.; Liya, Q.; Faganeli, J.; et al. Total mercury, methylmercury and selenium in mercury polluted areas in the province Guizhou, China. Sci. Total Environ. 2003, 304, 231-256. [CrossRef]

76. Matsuyama, A.; Yasuda, Y.; Yasutake, A.; Xiaojie, L.; Pin, J.; Li, L.; Mei, L.; Yumin, A.; Liya, Q. Detailed Pollution Map of an Area Highly Contaminated by Mercury Containing Wastewater from an Organic Chemical Factory in People's Republic of China. Bull. Environ. Contam. Toxicol. 2006, 77, 82-87. [CrossRef]

77. Rudd, J.W.; Bodaly, R.; Fisher, N.S.; Kelly, C.A.; Kopec, A.D.; Whipple, C. Fifty years after its discharge, methylation of legacy mercury trapped in the Penobscot Estuary sustains high mercury in biota. Sci. Total Environ. 2018, 642, 1340-1352. [CrossRef]

78. Turner, R.; Kopec, A.; Charette, M.; Henderson, P. Current and historical rates of input of mercury to the Penobscot River, Maine, from a chlor-alkali plant. Sci. Total Environ. 2018, 637-638, 1175-1186. [CrossRef] [PubMed]

79. Kopec, A.D.; Kidd, K.A.; Fisher, N.S.; Bowen, M.; Francis, C.; Payne, K.; Bodaly, R. Spatial and temporal trends of mercury in the aquatic food web of the lower Penobscot River, Maine, USA, affected by a chlor-alkali plant. Sci. Total Environ. 2019, 649, 770-791. [CrossRef]

80. Esbrí, J.M.; López-Berdonces, M.A.; Fernández-Calderón, S.; Higueras, P.; Díez, S. Atmospheric mercury pollution around a chlor-alkali plant in Flix (NE Spain): An integrated analysis. Environ. Sci. Pollut. Res. 2015, 22, 4842-4850. [CrossRef]

81. Fernández-Martínez, R.; Esbrí, J.M.; Higueras, P.; Rucandio, M.I. Comparison of mercury distribution and mobility in soils affected by anthropogenic pollution around chloralkali plants and ancient mining sites. Sci. Total Environ. 2019, 671, 1066-1076. [CrossRef]

82. Palanques, A.; Grimalt, J.O.; Belzunces, M.; Estrada, F.; Puig, P.; Guillén, J. Massive accumulation of highly polluted sedimentary deposits by river damming. Sci. Total Environ. 2014, 497-498, 369-381. [CrossRef] [PubMed]

83. Soto, D.X.; Roig, R.; Gacia, E.; Catalan, J. Differential accumulation of mercury and other trace metals in the food web components of a reservoir impacted by a chlor-alkali plant (Flix, Ebro River, Spain): Implications for biomonitoring. Environ. Pollut. 2011, 159, 1481-1489. [CrossRef] [PubMed]

84. Inácio, M.; Pereira, V.; Pinto, M. Mercury contamination in sandy soils surrounding an industrial emission source (Estarreja, Portugal). Geoderma 1998, 85, 325-339. [CrossRef]

85. Reis, A.T.; Rodrigues, S.M.; Araújo, C.; Coelho, J.P.; Pereira, E.; Duarte, A.C. Mercury contamination in the vicinity of a chlor-alkali plant and potential risks to local population. Sci. Total Environ. 2009, 407, 2689-2700. [CrossRef]

86. Ramalhosa, E.; Pato, P.; Monterroso, P.; Pereira, E.; Vale, C.; Duarte, A.C. Accumulation versus remobilization of mercury in sediments of a contaminated lagoon. Mar. Pollut. Bull. 2006, 52, 353-356. [CrossRef] [PubMed]

87. Sunderland, E.M.; Chmura, G.L. An inventory of historical mercury emissions in Maritime Canada: Implications for present and future contamination. Sci. Total Environ. 2000, 256, 39-57. [CrossRef]

88. Garron, C.; Gagné, F.; Ernst, W.; Julien, G.; Bernier, M.; Caldwell, C. Mercury Contamination of Marine Sediments and Blue Mussels (Mytilus edulis) in the Vicinity of a Mercury Cell Chlor-Alkali Plant in Dalhousie, New Brunswick, Canada. Water Qual. Res. J. 2005, 40, 1-15. [CrossRef]

89. Walker, T.R. Mercury concentrations in marine sediments near a former mercury cell chlor-alkali plant in eastern Canada. Mar. Pollut. Bull. 2016, 107, 398-401. [CrossRef] 
90. Sensen, M.; Richardson, D.H.S. Mercury levels in lichens from different host trees around a chlor-alkali plant in New Brunswick, Canada. Sci. Total Environ. 2002, 293, 31-45. [CrossRef]

91. Bravo, A.G.; Loizeau, J.-L.; Ancey, L.; Ungureanu, V.G.; Dominik, J. Historical record of mercury contamination in sediments from the Babeni Reservoir in the Olt River, Romania. Environ. Sci. Pollut. Res. 2008, 16, S66-S75. [CrossRef]

92. Bravo, A.G.; Cosio, C.; Amouroux, D.; Zopfi, J.; Chevalley, P.-A.; Spangenberg, J.E.; Ungureanu, V.-G.; Dominik, J. Extremely elevated methyl mercury levels in water, sediment and organisms in a Romanian reservoir affected by release of mercury from a chlor-alkali plant. Water Res. 2014, 49, 391-405. [CrossRef] [PubMed]

93. Stevens, J.B. Disposition of toxic metals in the agricultural food chain. 2. Steady-state bovine tissue biotransfer factors. Environ. Sci. Technol. 1992, 26, 1915-1921. [CrossRef]

94. Song, Z.; Li, P.; Ding, L.; Li, Z.; Zhu, W.; He, T.; Feng, X. Environmental mercury pollution by an abandoned chlor-alkali plant in Southwest China. J. Geochem. Explor. 2018, 194, 81-87. [CrossRef]

95. Bolaños-Alvarez, Y.; Alonso-Hernandez, C.M.; Morabito, R.; Díaz-Asencio, M.; Pinto, V.; Gómez-Batista, M. Mercury contamination of riverine sediments in the vicinity of a mercury cell chlor-alkali plant in Sagua River, Cuba. Chemosphere 2016, 152, 376-382. [CrossRef] [PubMed]

96. Feng, C.; Pedrero, Z.; Lima, L.; Olivares, S.; De La Rosa, D.; Berail, S.; Tessier, E.; Pannier, F.; Amouroux, D. Assessment of $\mathrm{Hg}$ contamination by a Chlor-Alkali Plant in riverine and coastal sites combining $\mathrm{Hg}$ speciation and isotopic signature (Sagua la Grande River, Cuba). J. Hazard. Mater. 2019, 371, 558-565. [CrossRef]

97. Perrot, V.; Epov, V.N.; Pastukhov, M.V.; Grebenshchikova, V.I.; Zouiten, C.; Sonke, J.E.; Husted, S.; Donard, O.F.X.; Amouroux, D. Tracing Sources and Bioaccumulation of Mercury in Fish of Lake Baikal-Angara River Using Hg Isotopic Composition. Environ. Sci. Technol. 2010, 44, 8030-8037. [CrossRef]

98. Navrátil, T.; Šimeček, M.; Shanley, J.B.; Rohovec, J.; Hojdová, M.; Houška, J. The history of mercury pollution near the Spolana chlor-alkali plant (Neratovice, Czech Republic) as recorded by Scots pine tree rings and other bioindicators. Sci. Total Environ. 2017, 586, 1182-1192. [CrossRef]

99. Covelli, S.; Emili, A.; Acquavita, A.; Koron, N.; Faganeli, J. Benthic biogeochemical cycling of mercury in two contaminated northern Adriatic coastal lagoons. Cont. Shelf Res. 2011, 31, 1777-1789. [CrossRef]

100. Raj, D.; Maiti, S.K. Sources, toxicity, and remediation of mercury: An essence review. Environ. Monit. Assess. 2019, 191, 566. [CrossRef]

101. Duan, P.; Khan, S.; Ali, N.; Shereen, M.A.; Siddique, R.; Ali, B.; Iqbal, H.M.; Nabi, G.; Sajjad, W.; Bilal, M. Biotransformation fate and sustainable mitigation of a potentially toxic element of mercury from environmental matrices. Arab. J. Chem. 2020, 13, 6949-6965. [CrossRef]

102. Wang, L.; Hou, D.; Cao, Y.; Ok, Y.S.; Tack, F.M.; Rinklebe, J.; O'Connor, D. Remediation of mercury contaminated soil, water, and air: A review of emerging materials and innovative technologies. Environ. Int. 2020, 134, 105281. [CrossRef] [PubMed]

103. Raj, D.; Kumar, A.; Maiti, S.K. Mercury remediation potential of Brassica juncea (L.) Czern. for clean-up of flyash contaminated sites. Chemosphere 2020, 248, 125857. [CrossRef] [PubMed]

104. Bestetti, G.; Gandolfi, I.; Franzetti, A. Microbiological Mercury Removal from Contaminated Materials. WO2009125341A2, 15 October 2009.

105. Lestan, D.; Finzgar, N.; Gerl, M.; Gluhar, S.; Lakovic, G.; Hamiti, B. Soil and Sedement Remediation. CA2942367A1, 19 September 2016.

106. Alden, D.F.; Birk, G.M.; Bang, S.; Harwell, J.H.; Shiau, B.J. Method and a Chemical Composition for Accelerated In-Situ Biochemical Remediation. U.S. Patent Application 20200261954A1, 20 August 2020.

107. Nick, L.; Liangdong, W.; Li, L. Stabilisation Curing Agent and Administering Method that Heavy-Metal Contaminated Soil or Solid Waste are Administered. CN104312591B, 13 October 2014.

108. Xia, M.; Chen, Z.; Li, Y.; Li, C.; Ahmad, N.M.; Cheema, W.A.; Zhu, S. Removal of Hg(ii) in aqueous solutions through physical and chemical adsorption principles. RSC Adv. 2019, 9, 20941-20953. [CrossRef]

109. Mahbub, K.R.; Bahar, M.; Labbate, M.; Krishnan, K.; Andrews, S.; Naidu, R.; Megharaj, M.; Bahar, M.; Krishnan, K. Bioremediation of mercury: Not properly exploited in contaminated soils! Appl. Microbiol. Biotechnol. 2017, 101, 963-976. [CrossRef] [PubMed] 
110. Grujić, S.; Vasić, S.; Radojević, I.; Čomić, L.; Ostojić, A. Comparison of the Rhodotorula mucilaginosa Biofilm and Planktonic Culture on Heavy Metal Susceptibility and Removal Potential. Water Air Soil Pollut. 2017, 228, 73. [CrossRef]

111. Looney, B.B.; Denham, M.E.; Vangelas, K.M.; Bloom, N.S. Removal of Mercury from Low-Concentration Aqueous Streams Using Chemical Reduction and Air Stripping. J. Environ. Eng. 2003, 129, 819-825. [CrossRef]

112. He, F.; Gao, J.; Pierce, E.; Strong, P.J.; Wang, H.; Liang, L. In situ remediation technologies for mercury-contaminated soil. Environ. Sci. Pollut. Res. 2015, 22, 8124-8147. [CrossRef]

113. Richard, J.-H.; Biester, H. Mercury removal from contaminated groundwater: Performance and limitations of amalgamation through brass shavings. Water Res. 2016, 99, 272-280. [CrossRef]

114. Huttenloch, P.; Roehl, K.E.; Czurda, K. Use of Copper Shavings to Remove Mercury from Contaminated Groundwater or Wastewater by Amalgamation. Environ. Sci. Technol. 2003, 37, 4269-4273. [CrossRef]

115. Subirés-Muñoz, J.; García-Rubio, A.; Vereda-Alonso, C.; Gomez-Lahoz, C.; Rodriguez-Maroto, J.M.; Garcia-Herruzo, F.; Paz-García, J.M. Feasibility study of the use of different extractant agents in the remediation of a mercury contaminated soil from Almaden. Sep. Purif. Technol. 2011, 79, 151-156. [CrossRef]

116. Randall, P.M.; Chattopadhyay, S. Mercury contaminated sediment sites-An evaluation of remedial options. Environ. Res. 2013, 125, 131-149. [CrossRef]

117. Kumar, M.; Singh, A.K.; Sikandar, M. Biosorption of Hg (II) from aqueous solution using algal biomass: Kinetics and isotherm studies. Heliyon 2020, 6, e03321. [CrossRef]

118. Park, C.M.; Katz, L.E.; Liljestrand, H.M. Mercury speciation during in situ thermal desorption in soil. J. Hazard. Mater. 2015, 300, 624-632. [CrossRef] [PubMed]

119. Faisal, A.A.; Sulaymon, A.H.; Khaliefa, Q.M. A review of permeable reactive barrier as passive sustainable technology for groundwater remediation. Int. J. Environ. Sci. Technol. 2017, 15, 1123-1138. [CrossRef]

120. Raj, D.; Kumar, A.; Maiti, S.K. Brassica juncea (L.) Czern. (Indian mustard): A putative plant species to facilitate the phytoremediation of mercury contaminated soils. Int. J. Phytoremed. 2020, 22, 733-744. [CrossRef] [PubMed]

121. Ackerman, J.T.; Kraus, T.E.; Fleck, J.A.; Krabbenhoft, D.P.; Horwath, W.R.; Bachand, S.M.; Herzog, M.P.; Hartman, C.A.; Bachand, P.A.M. Experimental Dosing of Wetlands with Coagulants Removes Mercury from Surface Water and Decreases Mercury Bioaccumulation in Fish. Environ. Sci. Technol. 2015, 49, 6304-6311. [CrossRef]

122. Rumayor, M.; Lopez-Anton, M.A.; Somoano, M.D.; Maroto-Valer, M.; Richard, J.-H.; Biester, H.; Martinez-Tarazona, M.; Maroto-Valer, M.M. A comparison of devices using thermal desorption for mercury speciation in solids. Talanta 2016, 150, 272-277. [CrossRef]

123. He, Z.; Siripornadulsil, S.; Sayre, R.T.; Traina, S.J.; Weavers, L.K. Removal of mercury from sediment by ultrasound combined with biomass (transgenic Chlamydomonas reinhardtii). Chemosphere 2011, 83, 1249-1254. [CrossRef]

124. Akimat of Pavlodar City. Report on the Implementation of the Development Program of the Pavlodar City Territory for 2016-2020. 2018. Available online: https:/www.akimat-pvl.gov.kz/post.php?id=2427 (accessed on 11 May 2020).

125. World Bank. Nura River Clean-Up Project. The World Bank Group. 2010. Available online: https://projects. vsemirnyjbank.org/ru/projects-operations/project-detail/P059803?lang=ru (accessed on 12 May 2020).

126. Dushkina, Y.N.; Urazgalieva, A.A.; Mustafina, V.V. Mercury contamination in the Republic of Kazakhstan: Current situation and measures for its minimization. Chem. Saf. 2018, 2, 237-243. (In Russian) [CrossRef]

Publisher's Note: MDPI stays neutral with regard to jurisdictional claims in published maps and institutional affiliations.

(C) 2020 by the authors. Licensee MDPI, Basel, Switzerland. This article is an open access article distributed under the terms and conditions of the Creative Commons Attribution (CC BY) license (http://creativecommons.org/licenses/by/4.0/). 